\title{
CARACTERIZACIÓN PETROGRÁFICA, GEOQUÍMICA Y GEOCRONOLOGÍA DE ROCAS GRANITOIDES PÉRMICAS AL OCCIDENTE DE LA PLATA Y PACARNÍ - HUILA, VALLE SUPERIOR DEL MAGDALENA - COLOMBIA
}

\author{
Gabriel Rodríguez G. ${ }^{1 *}$; Gilberto Zapata ${ }^{1}$; María Isabel Arango ${ }^{1}$ José Gilberto Bermúdez $^{1}$
}

DOI: http://dx.doi.org/10.18273/revbol.v39n1-2017002 (c) (1)

Forma de citar: Rodríguez, G., Zapata, G., Arango, M.I., y Bermúdez, J.G. 2017. Caracterización petrográfica, geoquímica y geocronología de rocas granitoides Pérmicas al occidente de La Plata y Pacarní - Huila, Valle Superior del Magdalena - Colombia. Boletín de Geología, 39(1): 41-68.

\section{RESUMEN}

El Granito de La Plata es una unidad de composición heterogénea, constituido por rocas graníticas de las series monzogranitos, sienogranitos, granodioritas y cuarzo-monzonitas que aflora en el flanco oriental de la Cordillera Central de Colombia en el sector del Valle Superior del Magdalena, entre los departamentos del Cauca y Huila. Hacia los bordes este cuerpo presenta localmente granitoides y migmatitas (protolito ígneo), con estructuras plegadas, estromáticas y nebulíticas, compuestas por bandas de granofels cuarzo feldespático que representan leucosomas y bandas de granofels de cuarzo-feldespato con hornblenda y biotita que corresponden a melanosomas. Tanto las rocas plutónicas como las migmatitas presentan afinidad calcoalcalina rica en $\mathrm{K}$, con contenidos de $\mathrm{SiO}_{2}$ que varían entre 58,92\% (migmatitas) y 77,39\% (sienogranitos). Los dos grupos de rocas exhiben correlación en el tren de cristalización en los diagramas Harker y se ubican indiscriminadamente entre las series metaluminosas y peraluminosas. Por su parte, en los diagramas multielementales de tierras raras y elementos trazas, las rocas graníticas y migmatíticas presentan anomalías negativas en $\mathrm{Nb}$, Ti y valores bajos de $\mathrm{P}$, lo cual se asocia con un ambiente de arco volcánico para todas las rocas. El análisis geocronológico U-Pb LA-ICP-MS en circones de siete (7) rocas entre granitos y migmatitas arrojan edades similares de cristalización, de $268,3 \pm 2,0 \mathrm{Ma}, 273,2 \pm 4,1$ y $277,9 \pm 2,1$ para rocas migmatíticas y de $269,0 \pm 3,0 \mathrm{Ma}, 270,0 \pm 2,7 \mathrm{Ma}, 272,0 \pm 6,8 \mathrm{Ma}$ y $274,8 \pm 2,3$ Ma para los granitos. Ambos grupos registran edades heredadas desde el Pérmico hasta el Paleo Proterozoico, lo cual sugiere aporte de los bloques de corteza continental que afloran al oriente de las rocas Pérmicas descritas en el presente estudio.

Palabras clave: rocas Pérmicas, geoquímica, geocronología.

\section{PETROGRAPHIC, GEOCHEMISTRY AND GEOCHRONOLOGICAL CHARACTERIZATION OF PERMIAN GRANITOIDS ROCKS TO THE WEST OF LA PLATA AND PACARNÍ - HUILA, UPPER MAGDALENA VALLEY - COLOMBIA}

\begin{abstract}
La Plata Granite is a granitic series with a heterogeneous composition that is outcropping at the eastern flank of the Central Cordillera of Colombia in the Upper Magdalena Valley area, between the Cauca and Huila departments. It is composed of monzogranites, syenogranites, granodiorites and quartz monzonites. At its edges, the unit includes migmatites and granitoids rocks with folded, stromaticand nebulitic structures. These migmatitic rocks are composed of quartz feldespatic granofels representing the leucosome, and quartz feldespatic granofels with hornblende and biotite corresponding to melanosome. Both granitic and migmatitic rocks have a high $\mathrm{K}$ rich calc-alkaline affinity, with $\mathrm{SiO}_{2}$ content ranging from 58,92\% (migmatites) and $77,39 \%$ (sienogranite). These two groups of rocks exhibit correlation in Harker diagrams and indiscriminately placed between metaluminous and peraluminous series. Furthermore, in the multi-element diagrams, there is a difference between the granitic and migmatitic rocks signatures, showing parallelism between them, suggesting similar origins associated with a volcanic arc setting given the low contents of $\mathrm{Nb}$, Ti and $\mathrm{P}$ for both groups of rocks. LA-ICP-MS U-Pb geochronology analysis in zircons obtained from seven (7) rocks yield similar crystallization ages for granites and migmatites; with ages of 268,3 $\pm 2,0 \mathrm{Ma}, 273,2 \pm 4,1$ and 277,9 $\pm 2,1 \mathrm{Ma}$ for migmatitic rocks and 269,0 $\pm 3,0 \mathrm{Ma}, 270,0 \pm 2,7 \mathrm{Ma}, 272,0 \pm 6,8 \mathrm{Ma}$ and $274,8 \pm 2,3 \mathrm{Ma}$ for the granitic rocks. Both groups point to inherited ages from the Permian to the Paleoproterozoic, which suggest the contribution of the continental crust blocks that appear to the east of the Permian rocks described in the present study.
\end{abstract}

Keywords: Permian rocks, geochemistry, geochronology.

${ }^{1}$ Grupo de Estudios Geológicos Especiales. Servicio Geológico Colombiano (SGC), Medellín, Colombia.

(*) grodriguez@sgc.gov.co, gzapata@sgc.gov.co, isabelara84@hotmail.com,jbermudez@sgc.gov.co 


\section{INTRODUCCIÓN}

Estudios anteriores denominaron de manera informal las rocas metamórficas que afloran al occidente de $\mathrm{La}$ Plata-Huila con el nombre de "Macizo de La Plata" (Grosse, 1935; Rodríguez, 1995a). Posteriormente INGEOMINAS realizó la cartografía geológica a escala 1:100.000 de esta región, con énfasis en información macroscópica y petrográfica, separando del Batolito de Ibagué (Plutón del Páez), las rocas metamórficas que fueron llamadas Ortogranito de La Plata, descritas como granitos de anatexis y migmatitas de probable edad Precámbrica (Rodríguez, 1995b; Rodríguez et al., 1998; Velandia et al., 1999; Velandia et al., 2001). Leal-Mejía (2011) publica una edad $\mathrm{U} / \mathrm{Pb}$ en una roca tomada al occidente de La Plata - Huila y le asigna al Ortogranito de La Plata una edad Pérmica.

Trabajos recientes realizados por el Servicio Geológico Colombiano (SGC) en el proyecto Magmatismo Jurásico del Valle Superior del Magdalena (VSM) y la Cuenca de Putumayo, permitieron el reconocimiento de nuevos afloramientos de rocas granitoides de edad Pérmica al sur de La Plata y al Occidente de Pacarní Huila, los cuales habían sido cartografiados como parte de los plutones jurásicos que afloran en el flanco oriental de la Cordillera Central por Rodríguez et al. (1998) y Marquínez et al. $(2002,2003)$.

El registro del magmatismo Pérmico en la región de Centroamérica y los Andes del Norte se extiende desde el sur y este de México (Arvizu et al., 2009) hasta el sur de la Cordillera Real en Ecuador (Litherland et al., 1994; Spikings et al., 2015), incluyendo el norte de los Andes en Colombia, (flanco oriental de la cordillera Central, Serranía de San Lucas, Sierra Nevada de Santa Marta). Datos geoquímicos muestran un magmatismo Pérmico afín con ambientes de arco de margen continental (Cardona et al., 2010, Rodríguez et al., 2014). Dataciones en $\mathrm{U}-\mathrm{Pb}, \mathrm{Ar}-\mathrm{Ar}$, datos de isótopos y petrografía sugieren una posible relación con los procesos de evolución tectónica de Pangea (Toussaint et al., 1978; Vinasco et al., 2006; Cardona et al., 2010; Spikings et al., 2015).

El presente estudio clarifica la distribución cartográfica de rocas ígneas y metamórficas Pérmicas en el flanco occidental del VSM y su relación con unidades plutónicas Jurásicas adyacentes. Se presentan nuevos análisis petrográficos y geoquímicos que permiten establecer el ambiente geotectónico de formación, además, se presenta nuevos datos geocronológicos obtenidos por el método U-Pb laser ablación ICP-MS en circones que permiten la correlación con unidades similares que afloran en el norte de Colombia.

\section{GEOLOGÍA REGIONAL}

Desde el punto de vista regional, las rocas granitoides de edad Pérmica que afloran al occidente de La Plata y Pacarní (Huila), se localizan dentro del terreno Chibcha, cerca de la zona de convergencia con el terreno Tahamí, terrenos que fueron definidos por Restrepo and Toussaint (1988), cuyo límite en el norte se ha considerado la Falla Otú-Pericos-Palestina y al sur la Falla de Chusma (FIGURA 1). El Terreno Chibcha, en el área de estudio, está conformado por un basamento de rocas metamórficas (migmatitas, granofels, granulitas, granitos de anatexia y gneises) de edad Precámbrica Nickeriense representados por el Grupo Garzón (Kroonenberg, 1982), el Granito de El Recreo (Rodríguez, 1995b; Velandia et al., 2001) los gneises de Guapotón y Mancagua (Kroonenberg, 1982; Priem et al., 1989; Rodríguez, 1995b; Velandia et al., 2001) y las Migmatitas de Las Minas (Velandia et al., 1996, 1999); por unidades sedimentarias Paleozoicas como la Formación El Hígado (Mojica et al., 1988; Velandia et al., 1999) y el Paleozoico de La Jagua (Stibane y Forero, 1969; Villarroel y Mojica, 1988; Velandia et al., 1999; Velandia et al., 2001). El Terreno Tahamí ha sido poco estudiado en este sector de la Cordillera Central de Colombia, aflora más al occidente sobre la Cordillera Central de Colombia, está constituido regionalmente por esquistos, cuarcitas, gneises, granofels y anfibolitas de edad Triásica (Botero, 1963; Hall et al., 1972; Feininger et al., 1972; González, 1980; Restrepo and Toussaint, 1988; Restrepo et al., 2009; Rodríguez et al., 2005; Vinasco et al., 2006).

Los granitos y migmatitas de La Plata (Pérmicos) afloran en la margen occidental del VSM, aparecen como bloques intruidos por la Cuarzomonzodiorita de Páez que hace parte del magmatismo de Arco del Jurásico inferior (Zapata et al., 2015; Rodríguez et al., 2015) y están parcialmente cubiertos por rocas piroclásticas ignimbríticas de la Formación Guacacallo descrita por Kroonenberg et al. (1981) (FIGURA 1).

Tectónicamente los granitos y migmatitas Pérmicas hacen parte de un bloque entre las Fallas Chusma al oriente y Avirama e Inza al Occidente, conforman este bloque rocas metamórficas del Complejo Aleluya (Ferreira et al., 2002), vulcanitas Jurásicas de la Formación Saldaña (Cediel et al., 1980 y 1981; Rodríguez et al., 2016) y plutones de arco del Jurásico Inferior, como la Cuarzomonzodiorita de Páez (Zapata et al., 2015), la Cuarzomonzonita de Los Naranjos (Rodríguez et al., 2015); Cuarzomonzonita de Anchique (Arango et al., 2015) y Cuarzomonzonita de San Cayetano (Bermúdez et al., 2015). 


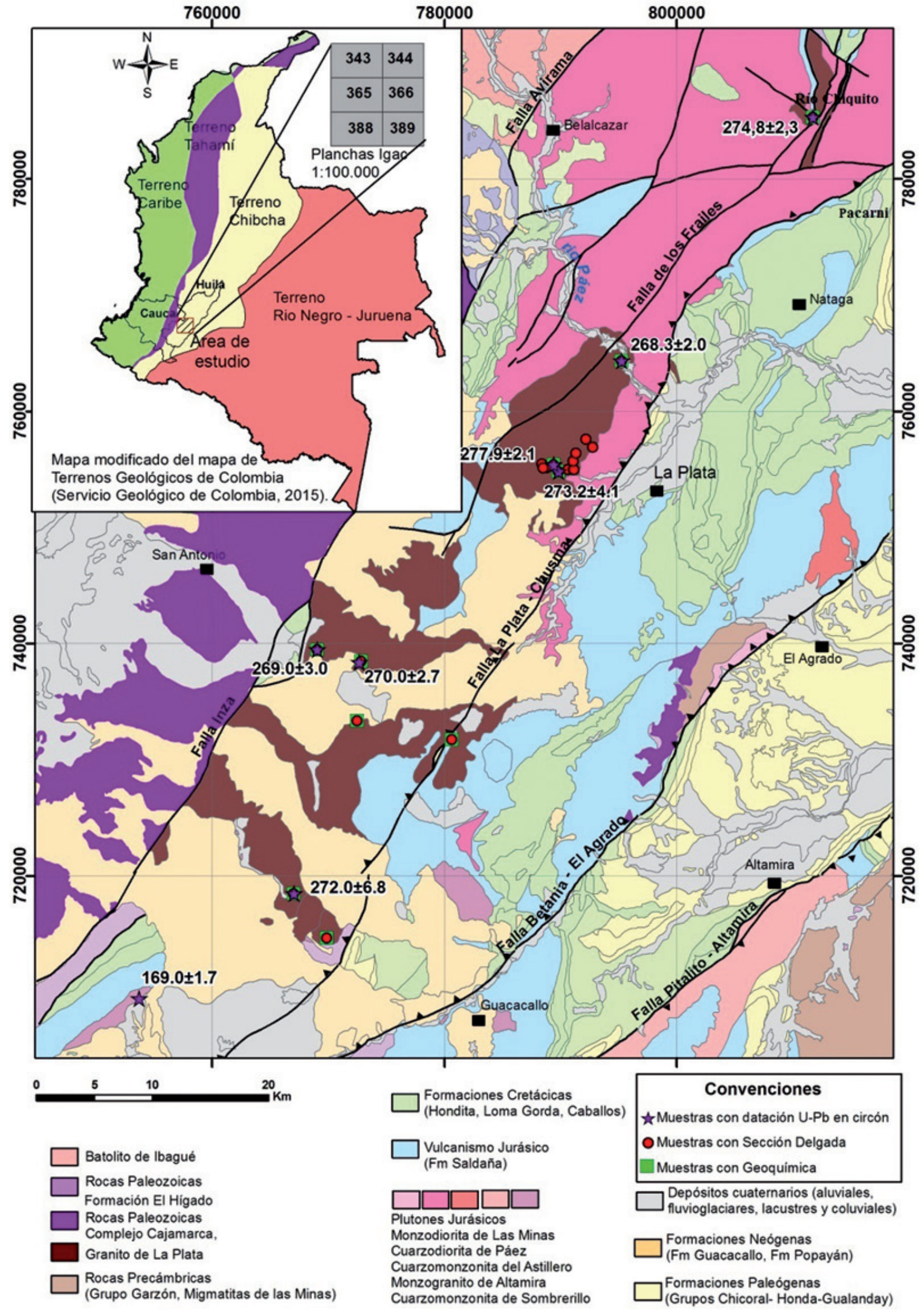

FIGURA 1. Localización y muestreo de afloramientos de rocas Pérmicas al occidente de La Plata. 


\section{ESTUDIOS PREVIOS}

Con el nombre de Macizo de La Plata - La Topa, Grosse (1935), describe un macizo granodiorítico al occidente del Municipio de La Plata-Huila y lo considera post-Cretácico, con composición poco uniforme de dioritas cuarzosas y subordinados granitos de color rojo. La unidad fue considerada como un intrusivo de composición granodiorítica-granítica por Álvarez y Linares (1983), con "segmentos" o xenolitos de rocas metamórficas migmatíticas de posible edad Precámbrica (Fuquen y Núñez, 1989). Posteriormente Álvarez (1979) menciona que los plutones situados al sur del Batolito de Ibagué, entre los cuales se encuentra el Plutón de La Plata, presentan contenidos más altos en $\mathrm{K}$ y $\mathrm{Rb}$, sugiriendo una ausencia de correlación magmática entre estos cuerpos.

Rodríguez (1995a) describe la petrografía de las rocas que afloran en la parte occidental del municipio de la Plata, encontrando rocas de composición granodiorítica-tonalítica, con texturas ígneas que denominó bajo el nombre de Plutón de Páez, nombre propuesto anteriormente por Hubach y Alvarado (1932). Dentro de esta zona separa cartográficamente las rocas con texturas metamórficas, para las cuales retoma el nombre de Macizo de La Plata dado por Grosse (1935); considera esta última unidad como un cuerpo metamórfico formado en condiciones de presión y temperatura de facies anfibolita y granulita, constituido por granitos anatécticos, granulitas cuarzo-feldespáticas y gneises migmatíticos, los cuales separa por primera vez de la Cuarzomonzodiorita de Páez (anteriormente Batolito de Ibagué o Plutón del Páez).

Velandia et al. (2001), asignan el nombre de Ortograníto de La Plata a las rocas metamórficas anteriormente nombradas Macizo de La Plata y define un área de exposición de $50 \mathrm{Km}^{2}$ hacia el occidente del municipio de La Plata, constituida por granitoides cuarzo feldespáticos formados por ultra metamorfismo (anatexis), localmente con granulitas y migmatitas. Estos autores indican contactos de tipo intrusivo con el Batolito de Ibagué hacia el lado oriental de la unidad, mientras que hacia el occidente se encuentra cubierto por depósitos laháricos y tobas ignimbríticas de la Formación Guacacallo; consideran una probable edad Precámbrica para esta unidad por correlación con el Macizo de Garzón. Leal-Mejía (2011) publica una edad del Ortogranito de la Plata realizada por el método $\mathrm{U}-\mathrm{Pb}$ en circones ígneos de $274,8 \pm 6 \mathrm{Ma}$, y correlaciona esta unidad con granitoides de similar edad datados en la Sierra Nevada de Santa Marta (Cardona et al., 2010b), el Metagranito de Uray en la Guajira (Weber et al., 2010), el Gneis de Nechí en la Serranía de San Lucas (Restrepo et al. 2010; Rodríguez et al., 2014), y un Granitoide del sur de Guamocó en el bloque Tolima (Leal-Mejía, 2011), cuerpos que afloran en posición tectónica similar.

\section{TECNICAS ANALÍTICAS}

En el presente estudio se realizaron actividades de compilación de información, control de campo y muestreo, elaboración de secciones delgadas y análisis petrográfico tanto de muestras recolectadas en este estudio como de muestras de proyectos anteriores que reposan en los laboratorios del Servicio Geológico Colombiano (SGC). Los análisis químicos se realizaron en el laboratorio del Servicio Geológico Colombiano sede Bogotá (www.sgc.gov.co), los óxidos mayores se determinaron por el método de fluorescencia de rayos $\mathrm{X}$, incluyendo los elementos trazas $\mathrm{V}, \mathrm{Mo}, \mathrm{Nb}, \mathrm{Ta}, \mathrm{W}$, $\mathrm{Zr}$ y Hf y para el resto de elementos traza y tierras raras se utilizó el equipo de espectrometría de masas con plasma acoplado inductivamente (ICP-MS). Para la interpretación de los óxidos mayores se realizó el recalculo teniendo en cuenta los valores de pérdidas por ignición (LOI) fueran menores al 3\%.

La separación de minerales densos se realizó en el laboratorio químico del Servicio Geológico Colombiano sede Medellín, utilizando el método de bateo, separación magnética con un equipo Frantz y finalmente el montaje de los circones se hizo de manera manual utilizando lupa binocular para sacar los circones y montarlos en una cinta colocada sobre un vidrio de $5 \mathrm{~cm} \times 5 \mathrm{~cm}$.

Los cristales de circón fueron seleccionados cuidadosamente bajo un microscopio binocular, siendo montados en una cinta y posteriormente llevados a una probeta (un anillo plástico de 2,5 $\mathrm{cm}$ de diámetro) que se rellena de resina epóxica (Struers Epofix), dejándose endurecer. El cilindro obtenido se desbasta por medio de papel lija (\# 800, 1.500 y 3.000) hasta exponer una superficie lo más cercana posible a la mitad ecuatorial de los circones. Antes de los análisis in situ por ablación láser, las superficies pulidas de los granos de circón fueron fotografiadas en catodoluminiscencia (CL) por medio del empleo de un luminoscopio ELM-3R. Las imágenes de CL y luz reflejada fueron obtenidas con el propósito de caracterizar la estructura interna de los circones y elegir los sitios potenciales para los análisis de $\mathrm{U}-\mathrm{Pb}$, observando el zonamiento relacionado a los 
cambios de composición química de los circones, para poder detectar posibles inclusiones, sobrecrecimientos metamórficos o herencias que cambiarían el sentido de la interpretación de los datos analíticos. Una vez realizada la CL se procede a seleccionar los puntos más idóneos para el fechamiento, observando las imágenes de CL y la homogeneidad de los granos, teniendo en cuenta el tamaño del punto analítico que se empleará.

Los análisis geocronológicos se realizaron en el laboratorio de Estudios Isotópicos (LEI), en el Centro de Geociencias de la Universidad Nacional Autónoma de México (UNAM), campus Juriquilla, con la siguiente metodología: las concentraciones de U y Th fueron calculadas empleando un circón estándar externo de acuerdo a Paton et al. (2010). Las incertidumbres de sigma 2 propagadas se lograron según Paton et al. (2010). Las relaciones ${ }^{207} \mathrm{~Pb} /{ }^{206} \mathrm{~Pb}$, edades y errores se calcularon según Petrus and Kamber (2012). Los puntos analizados son de 23 micrómetros, utilizando un protocolo de análisis modificado de Solari et al. (2010). Los datos se midieron empleando un Thermo $X$ series QICPMS acoplado a un Resonetics, estación de trabajo láser excimer Resolución M050. Se realizó un análisis estadístico con el fin de mejorar el rango de confiabilidad de la edad proporcionada por el laboratorio, teniendo en cuenta la relación $\left.\left[\left({ }^{207} \mathrm{~Pb} /{ }^{235} \mathrm{U}\right)-\left({ }^{206} \mathrm{~Pb} /{ }^{238} \mathrm{U}\right) /{ }^{206} \mathrm{~Pb} /{ }^{238} \mathrm{U}\right)\right]$, eliminando los datos de circones con valores discordantes que estuvieran, en general, por encima de $15 \%$ y errores de más de $5 \%$. Los gráficos de concordia e histogramas se elaboraron en el software de Isoplot/Ex vers, 4,15 (Ludwig, 2008).

Dataciones complementarias U-Pb se realizaron en el laboratorio de ablación laser del Servicio Geológico Colombiano que cuenta con un equipo de ablación Photon Machines con un láser excímer de $193 \mathrm{~nm}$, acoplado a un espectrómetro de masas tipo Element 2. En este análisis se utilizaron como patrones de referencia los circones Plesovice, 91500 y M, Dromedry. Los puntos analizados en los circones son de 20 micrones de diámetro y la reducción de datos se realizó utilizando el programa Iolite IGROpro. Se utilizó como tiempos de integración para la línea base $0 \mathrm{~s}-38 \mathrm{~s}$ y para las muestras y patrones de referencia $32,5 \mathrm{~s}-8 \mathrm{~s}$, tiempos que concuerdan con el tiempo de corrida de los análisis. Los Isótopos utilizados para la integración manual son ${ }^{238} \mathrm{U},{ }^{206} \mathrm{~Pb}$ y ${ }^{204} \mathrm{~Pb}$. Los resultados finales corresponden a la media de los datos obtenidos luego de aplicar una discriminación de datos a 2 desviaciones estándar. El procesamiento se lleva a cabo con las rutinas de Isoplot V4.15 (Ludwig,
2012) y la corrección por plomo común se realiza de acuerdo con el modelo de evolución según Stacey and Krammers (1975).

\section{DESCRIPCIÓN MACROSCÓPICAY Y MICROSCÓPICA}

Las rocas de edad Pérmica objeto de este trabajo, se extienden espacialmente, en dos áreas diferentes sobre el flanco oriental de la Cordillera Central en el departamento del Huila: Un primer afloramiento se localiza al occidente del municipio de Pacarní cerca al corregimiento de Río Chiquito-Huila, donde se presenta un bloque de granofels con contactos fallados y un cuerpo de granito rosado intruído por charnoquitas de la Cuarzomonzodiorita de Páez (plancha geológica 344 -Tesalia, Marquínez et al., 2002). La segunda área de exposición se presenta al sur occidente del municipio de La Plata, en las planchas 365 Coconuco (Marquínez et al., 2003) y 366 Garzón (Rodríguez et al., 1998), aparece como ventanas entre la cubierta volcanoclástica de lahares e ignimbritas de la Formación Guacacallo (FIGURA 1). Las rocas metamórficas con estructuras migmatíticas afloran en el norte contra el Río Páez y al occidente de La Plata, mientras los granitos afloran como ventanas más al sur y en el bloque norte cerca de Río Chiquito, todas ellas intruidas por la Cuarzomonzodiorita de Páez.

La descripción macroscópica y microscópica se realiza por separado de los cuerpos de migmatíticas y granitoides con estructuras nebuliticas de los granitos rosados de aspecto ígneo. Para la caracterización petrográfica se analizaron doce rocas (12) y se compilaron y revisaron 16 descripciones del trabajo de Rodríguez (1995a) (TABLA 1); conservando la clasificación y los porcentajes del trabajo original. Los datos se grafican en el triángulo QAP (Streckeisen, 1976), incluyendo granitos y migmatitas (FIGURA 2).

Rodríguez (1995a) clasificó las rocas del Ortogranito de La Plata (Macizo de La Plata) como monzogranitos de anatexis, gneises migmatíticos de cuarzoplagioclasa-hornblenda con microclina y biotita, granulitas cuarzo-feldespáticas con ortopiroxeno, clinopiroxeno y hornblenda; predominando los monzogranitos y los gneises migmatíticos. En el presente estudio se extraen del Ortogranito de La Plata las rocas clasificadas como granulitas ya que han sido clasificadas como charnoquitas que hacen parte de la Cuarzomonzodiorita de Páez, con edades entre 181 y $186 \mathrm{Ma}$ (Zapata et al., 2015). 
Caracterización petrográfica, geoquímica y geocronología de rocas granitoides Pérmicas

al occidente de La Plata y Pacarní-Huila, Valle Superior del Magdalena-Colombia

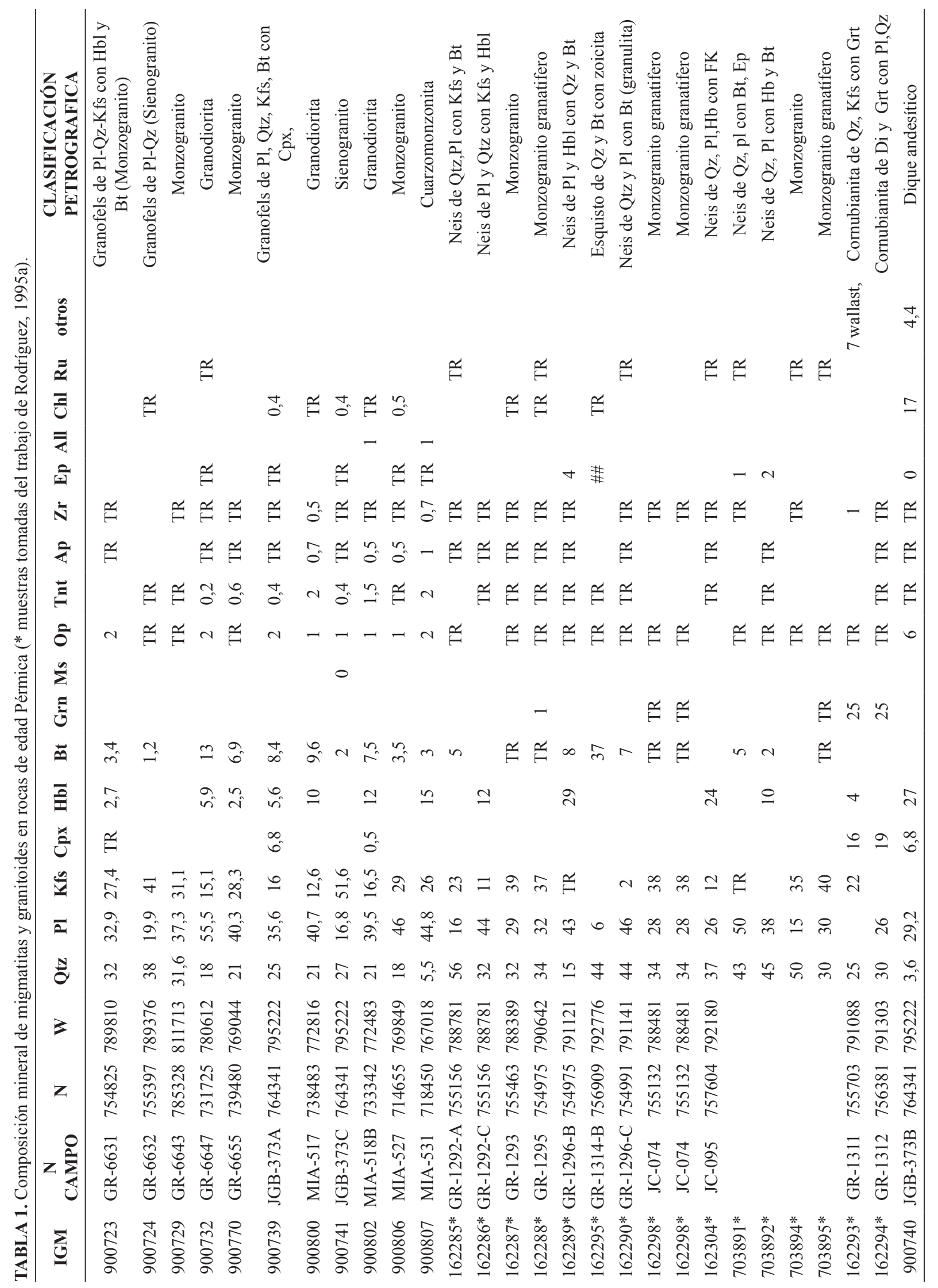




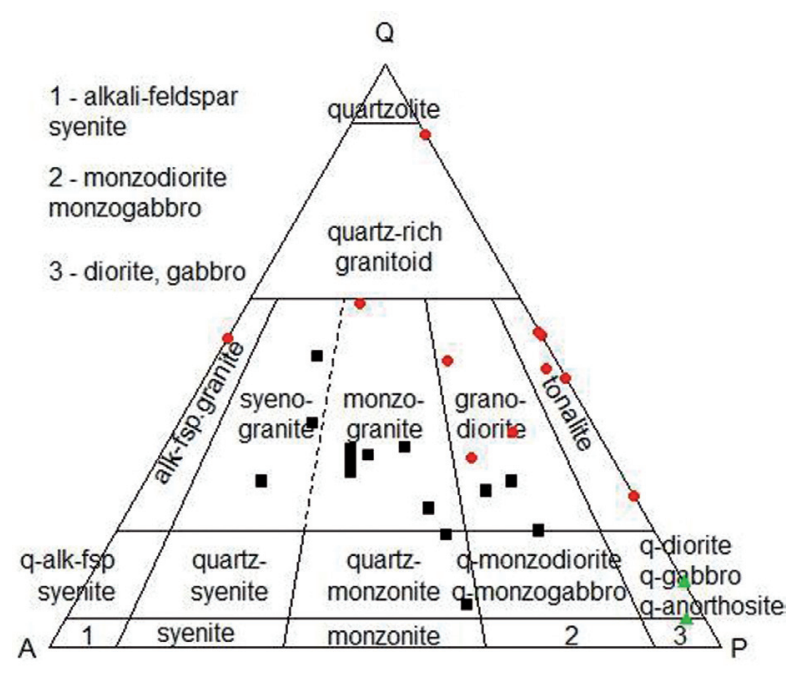

FIGURA 2. Clasificación modal de rocas de edad Pérmica que afloran al occidente de La Plata y Pacarní - Huila. Cuadros negros-granitos; rombos rojos-migmatitas (granofels); triángulos verdes-rocas de dique.

\section{Rocas Migmatíticas y Granitoides}

Las migmatitas de edad Pérmica que afloran al occidente de La Plata, están constituidas por bandas de granofels cuarzo feldespáticos y bandas de granofels de cuarzo-feldespato con hornblenda y biotita; tienen estructuras migmatiticas bandeadas, plegadas, estromáticas, junto a granofels (granitoides) con estructuras nebulíticas (diatexitas y restitas) (FIGURA 3).

Las migmatitas están compuestas por bandas de espesor centimétrico a decimétrico de color gris oscuro (melanosoma) y blanco (leucosoma) que varían en tamaño de grano y textura. Estas bandas presentan límites netos a transicionales difusos. Las rocas son faneríticas de grano medio a fino, con textura granoblástica que puede o no tener ligera orientación mineral, pueden ocurrir estructuras locales nebulíticas y plegadas, así como bandas irregulares y difusas de composición más básica que conservan restos de la foliación marcada por concentración de biotita y anfíbol.

El leucosoma está conformado por rocas granitoides de color blanco moteadas de negro por los minerales máficos; faneríticas de grano medio a fino con textura granular-granoblástica, de composición cuarzo feldespática, en bajas concentraciones pueden tener biotita y anfíbol que marcan algunas veces una foliación incipiente. El melanosoma corresponde a bandas de granofels anfibólico, localmente atravesados y englobados por el leucosoma.

Los granofels tienen texturas granoblásticas, localmente con crecimiento de minerales máficos en forma de atolón (textura descrita por Spry, 1969) e incipiente orientación mineral, están constituidos por cuarzo, plagioclasa, microclina y minerales máficos como biotita, hornblenda, epidota y clinopiroxeno; los minerales accesorios más frecuentes son titanita, apatito, circón, rutilo y opacos. En el triángulo de Streckeisen (1976) (FIGURA 2), las rocas grafican dentro de los campos de las tonalitas y las granodioritas (melanosoma) y las bandas de leucosoma en el campo de los monzogranitos y sienogranitos.

Los granitoides están constituidos por cuarzo, plagioclasa, feldespato potásico y biotita $<1 \%$; además, pueden presentar granate $<1 \%$ y clinopiroxeno; los minerales accesorios son opacos, apatito, titanita, circón, allanita y rutilo (FIGURA 5).

La plagioclasa varía entre andesina y bitownita, con predominio de andesina sódica, aparece en cristales xenoblásticos a subidioblásticos, con maclas de albita y albita-Carlsbad, intercrecida localmente con cuarzo formando texturas mirmequíticas. El cuarzo es xenoblástico, puede estar incluido en los feldespatos y en hornblenda como cuarzo en gotas (drops). El feldespato corresponde a microclina, se encuentra en cristales xenoblásticos con pertitas en parches y bordes de reacción con plagioclasa. La biotita es de color marrón a marrón verdoso con pleocroísmo marrón claro a verde pálido, tiene extinción en estructura de arce moteado (extinción en biotitas descrita por Heinrich, 1970), para biotitas y moscovitas), en algunas rocas con incipiente orientación, e inclusiones de circón con halos pleocróicos, titanita y leve alteración a clorita. La hornblenda ocurre en cristales xenoblásticos de color verde, presenta texturas de tipo net y atolón con crecimiento blástico intergranular entre los cristales de cuarzo-plagioclasa y feldespato, generando texturas poiquiloblásticas con inclusiones subredondeadas de estos minerales, en algunas rocas son abundantes las inclusiones de microcristales de titanita romboidal localizada en los límites entre cristales. 


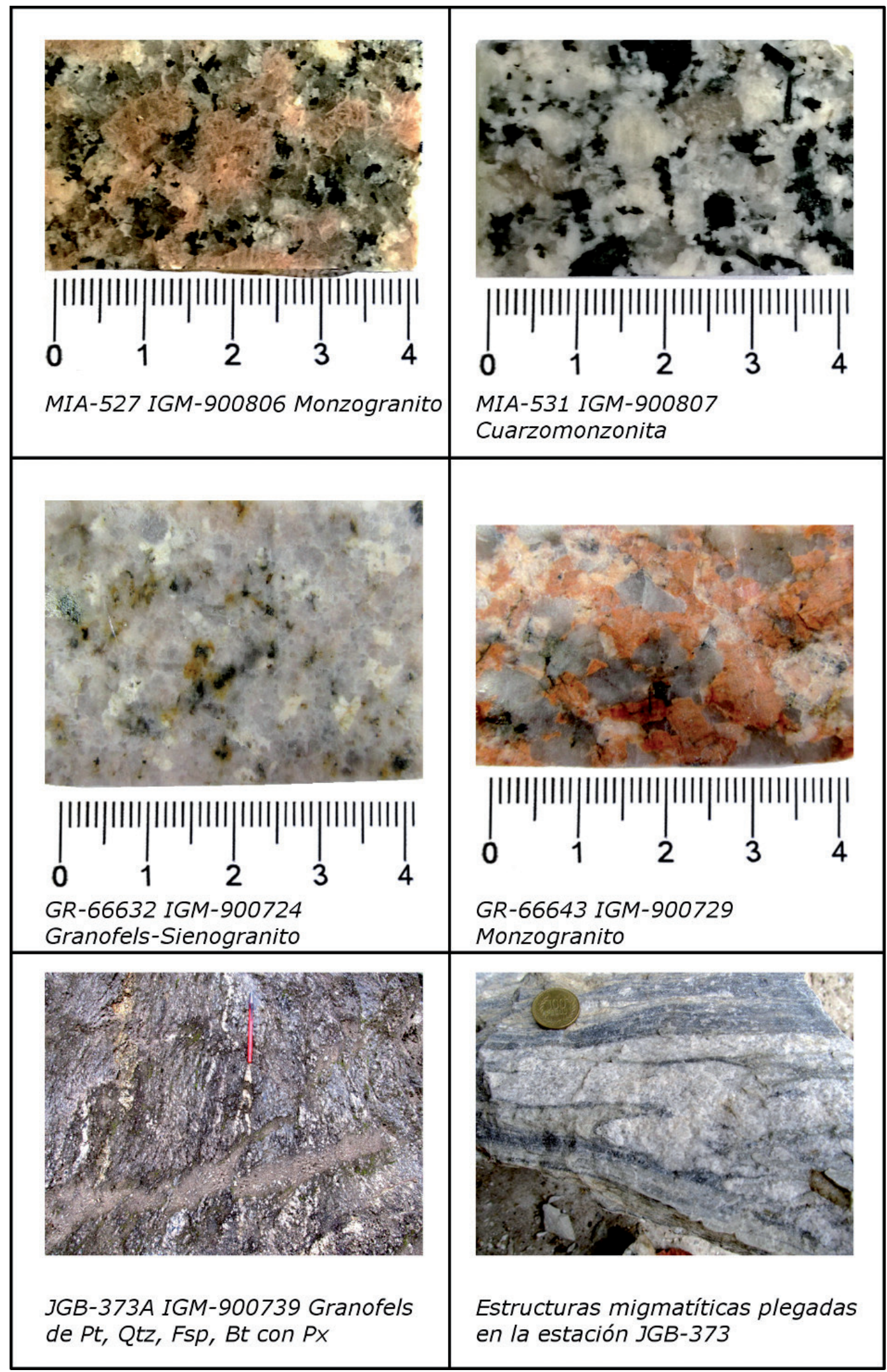

FIGURA 3. Aspecto macroscópico de rocas granitoides y migmatíticas de edad Pérmica al occidente de La Plata y Pacarní Huila. 
El piroxeno corresponde a diópsido, es incoloro a ligeramente verde pálido y se presenta (roca JGB393A) como cristales xenoblásticos poiquiloblásticos con inclusiones de plagioclasa, biotita, opacos y cuarzo, presenta crecimientos blásticos intergranulares mostrando texturas en atolón, se retrograda a hornblenda en parches y coronas de anfíbol actinolítico, marca una leve orientación mineral y se encuentra asociado a bandas dentro de la roca (FIGURA 4).
La titanita aparece como cristales idioblásticos de forma romboidal, de color pardo, generalmente crece en bordes de contacto de hornblenda y biotita. Los circones ocurren en microcristales xenomórficos de formas ovaladas, y desarrollan halo pleocroico en las biotitas. El apatito es idiomórfico hexagonal como inclusión en minerales principales.

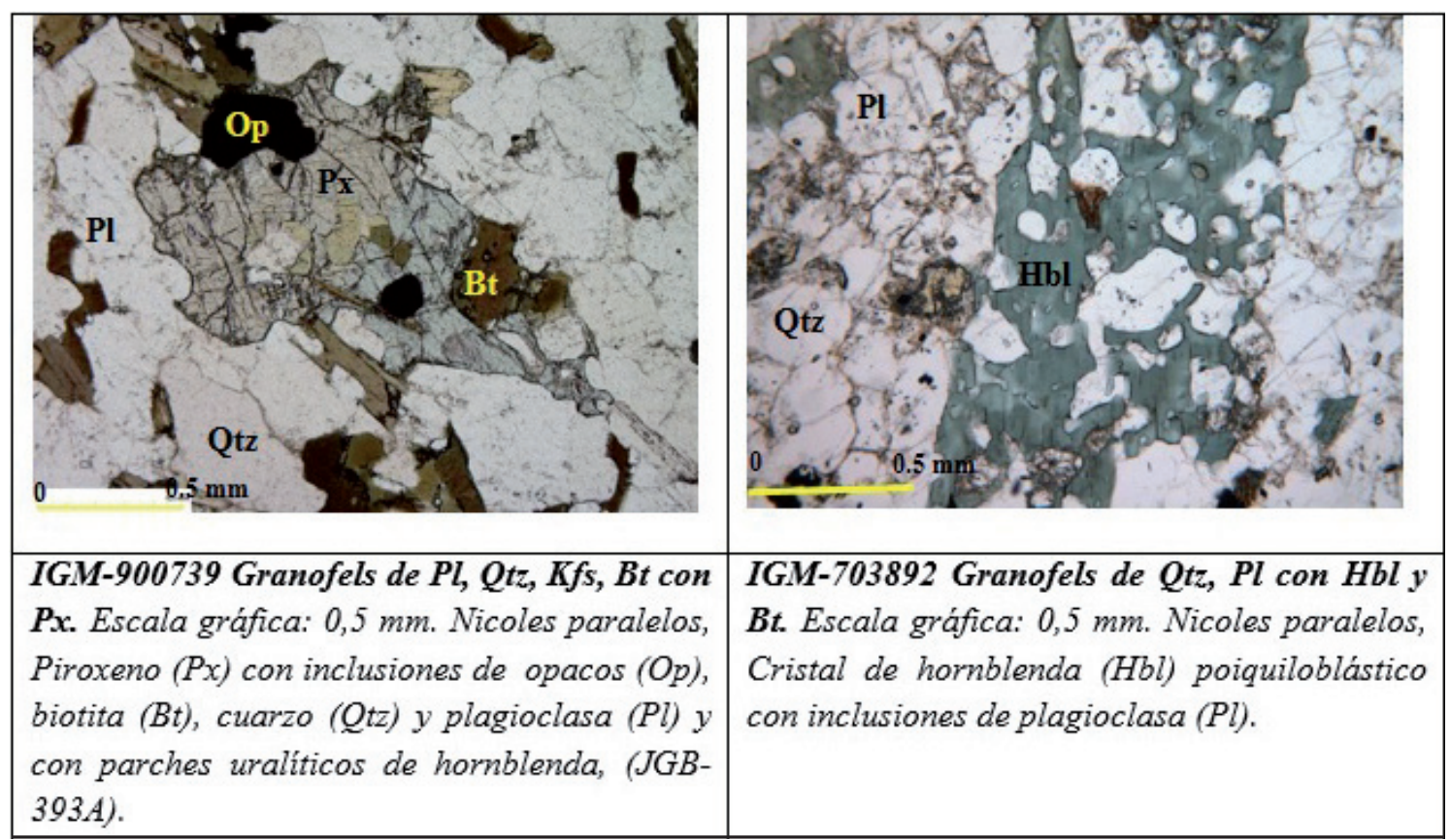

FIGURA 4. Aspecto microscópico de las rocas migmatíticas de edad Pérmica al occidente de La Plata y Pacarní - Huila.

\section{Granitos}

Los granitos son de color rosado moteados de blanco a ligeramente moteados de negro, y localmente son blancos moteados de negro, tienen textura granular fanerítica de grano medio, generalmente masiva y homogénea (FIGURA 5). Están constituidas por cuarzo de color blanco lechoso a gris ahumado, plagioclasa de color blanco y feldespato alcalino de color rosado y blanco en algunas rocas; como minerales máficos se presentan hornblenda y biotita en cantidades variables. Las rocas se clasificaron petrográficamente como monzogranitos y subordinados sienogranitos, granodioritas y cuarzomonzonitas.

El cuarzo se encuentra en cristales anhedrales inequigranulares, de tamaños variables entre $0,2 \mathrm{~mm}$ y $2,5 \mathrm{~mm}$, pueden formar agrupaciones policristalinas con bordes irregulares, en algunas rocas presenta inclusiones de agujas aciculares de rutilo. La plagioclasa se presenta como cristales subhedrales a euhedrales de tamaños entre 0,5 y $4,0 \mathrm{~mm}$, inequigranulares, con maclas mal desarrolladas de tipo albita y albita-Carlsbad; varía entre oligoclasa y andesina sódica (An19 a An33) siguiendo el método de Michel-Lévy en macla de albita, pudiendo tener intercrecimientos mirmequíticos con cuarzo en contacto con el feldespato alcalino. El feldespato alcalino corresponde a microclina y ortosa pasando a microclina, con desmezclas pertíticas en filoncillos a lo largo del clivaje del mineral y en parches.

La biotita forma agrupaciones de láminas finas de tamaños entre $0,2 \mathrm{~mm}$ y $1,5 \mathrm{~mm}$, de color verde oliva con un pleocroísmo $\mathrm{X}$ : amarillo $\mathrm{Y}=\mathrm{Z}$ : pálido verde oliva a marrón oscuro, en algunas rocas tiene simplectitas de cuarzo hacia los bordes y se altera a clorita con separación residual de titanita y magnetita. La hornblenda no está presente en todas las rocas graníticas, son subhedrales y anhedrales inequigranulares de color verde, con pleocroísmo $\mathrm{X}$ : verde manzana, $\mathrm{Y}$ : verde manzana medio y $\mathrm{Z}$ : verde oliva, localmente con restos de cristales de clinopiroxeno hacia el núcleo y biotita a lo largo de los planos de clivaje. 


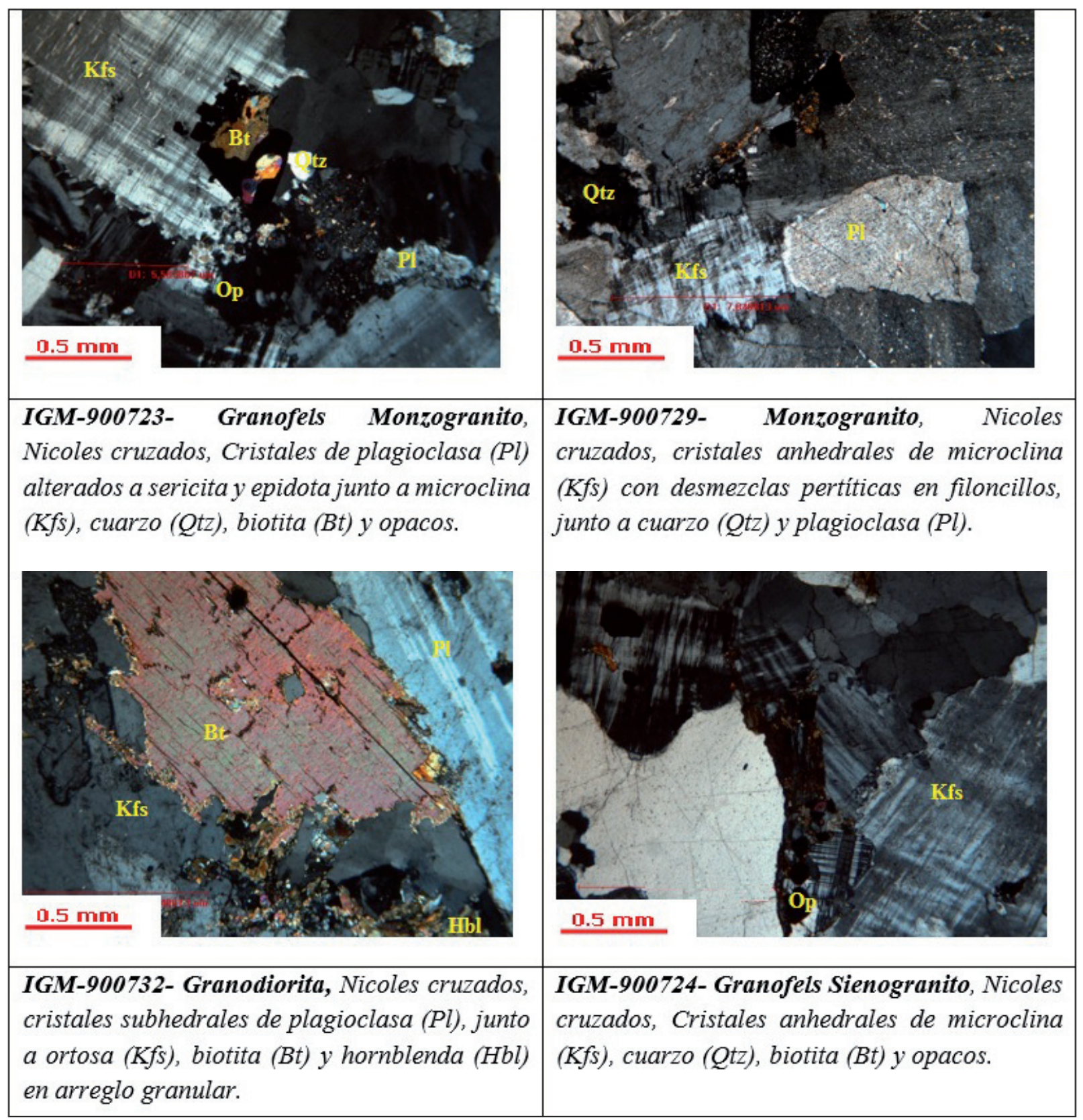

FIGURA 5. Aspecto microscópico de rocas granitoides en el Granito de La Plata.

Los minerales accesorios son opacos en cristales subhedrales a euhedrales, de tamaños menores a 0,3 $\mathrm{mm}$, generalmente incluidos en hornblenda y biotita; circón en cristales euhedrales prismáticos a hexagonales, incluidos en los minerales principales; apatito y rutilo en forma de agujas aciculares dentro de cristales de cuarzo.

\section{Diques}

El Granito de La Plata está atravesado por diques de cuarzo lechoso, pegmatitas cuarzo feldespáticas, diques graníticos con texturas aplíticas sacaroidales y diques básicos de andesitas basálticas de colores grises a verde oscuro.

\section{GEOQUÍMICA}

En este estudio se realizó el análisis geoquímico a 10 muestras de roca que corresponden a granitos y migmatitas de probable edad Pérmica. Se comparan los resultados químicos de los granitos y las migmatitas en los diferentes gráficos con el objeto de determinar si fueron originados durante un mismo evento ígneo y posteriormente fueron afectados por metamorfismo. 
En la TABLA 2 se muestra los resultados de óxidos mayores.

Según los datos de óxidos mayores, los contenidos de $\mathrm{SiO}_{2}$ varían entre $58,92 \%$ para la muestra JGB-373A correspondiente a un granofels y $77,39 \%$ para rocas granitoides de composición sienogranítica (GR-6632); El $\mathrm{TiO}_{2}$ en todas las muestras es $<1 \%$, se presenta valores bajos de $\mathrm{Al}_{2} \mathrm{O}_{3}$ entre $16,7 \%$ y $12,1 \%, \mathrm{Fe}_{2} \mathrm{O}_{3}$ entre $6,7 \%$ y $0,68 \%$. Debido al escaso contenido de minerales ferromagnesianos en las rocas ácidas, el
$\mathrm{MgO}$ varía de $3,1 \%$ a menos del $0,3 \%$, el $\mathrm{CaO}$ entre $6,2 \%$ y $0,32 \%$ y el $\mathrm{P}_{2} \mathrm{O}_{5}$ entre $0,26 \%$ y menos de $0,05 \%$. $\mathrm{MgO}, \mathrm{CaO}$ y $\mathrm{P}_{2} \mathrm{O}_{5}$ disminuyen a medida que aumenta el contenido de $\mathrm{SiO}_{2}$ (FIGURA 6). El $\mathrm{Na}_{2} \mathrm{O}$ presenta valores relativamente constantes entre $3 \%$ y $4 \%$ para la mayoría de las muestras y únicamente las rocas GR6631 y GR-6632 que son rocas migmatíticas tienen valores $<3 \%$. El $\mathrm{K}_{2} \mathrm{O}$ aumenta a medida que aumenta el contenido de $\mathrm{SiO}_{2}$ y está acorde con el aumento de feldespato alcalino en las rocas, con valores entre $2,73 \%$ y $7,21 \%$.

TABLA 2. Composición química de los óxidos mayores de rocas de edad Pérmica al occidente de La Plata y Pacarní - Huila.

\begin{tabular}{ccccccccccc}
\hline $\mathbf{I G M}$ & $\mathbf{9 0 0 7 2 9}$ & $\mathbf{9 0 0 7 3 2}$ & $\mathbf{9 0 0 7 7 0}$ & $\mathbf{9 0 0 8 0 0}$ & $\mathbf{9 0 0 8 0 2}$ & $\mathbf{9 0 0 8 0 6}$ & $\mathbf{9 0 0 8 0 7}$ & $\mathbf{9 0 0 7 2 3}$ & $\mathbf{9 0 0 7 2 4}$ & $\mathbf{9 0 0 7 3 9}$ \\
\hline $\mathbf{N ~ C A M P O}$ & GR-6643 & GR-6647 & GR-6655 & MIA-517 & MIA-518B & MIA-527 & MIA-531 & GR-6631 & GR-6632 JGB-373A \\
$\mathbf{N}$ & 785328 & 731725 & 739480 & 738483 & 733342 & 714655 & 718450 & 754825 & 755397 & 764341 \\
$\mathbf{W}$ & 811713 & 780612 & 769044 & 772816 & 772483 & 769849 & 767018 & 789810 & 789376 & 795222 \\
$\mathbf{S i O}$ & 76,56 & 62,88 & 69,8 & 60,85 & 62,18 & 74,76 & 66,05 & 73,34 & 77,39 & 58,92 \\
$\mathbf{T i O}_{2}$ & 0,15 & 0,73 & 0,47 & 0,82 & 0,83 & 0,2 & 0,61 & 0,13 & 0,11 & 0,85 \\
$\mathbf{A l}_{2} \mathbf{O}_{\mathbf{3}}$ & 13,18 & 16,03 & 14,72 & 16,5 & 16,11 & 13,26 & 15,45 & 13,13 & 12,14 & 16,74 \\
$\mathbf{F e}_{2} \mathbf{O}_{3}$ & 0,72 & 5,61 & 3,21 & 5,98 & 5,59 & 1,58 & 4,24 & 2,43 & 0,68 & 6,72 \\
$\mathbf{M g O}$ & $<0,10$ & 2,51 & 1,11 & 2,46 & 2,38 & 0,3 & 1,69 & 0,43 & $<0,10$ & 3,1 \\
$\mathbf{C a O}$ & 0,14 & 4,44 & 1,86 & 5 & 4,87 & 1,08 & 3,84 & 2,67 & 0,32 & 6,2 \\
$\mathbf{N a}_{\mathbf{2}} \mathbf{O}$ & 3,54 & 3,21 & 3,31 & 3,82 & 3,89 & 3,31 & 3,69 & 2,5 & 1,83 & 3,21 \\
$\mathbf{K}_{\mathbf{2}} \mathbf{O}$ & 5,27 & 3,4 & 4,09 & 2,82 & 2,9 & 4,9 & 3,37 & 4,33 & 7,21 & 2,73 \\
$\mathbf{P}_{2} \mathbf{O}_{\mathbf{5}}$ & $<0,024$ & 0,196 & 0,159 & 0,338 & 0,338 & 0,052 & 0,212 & 0,059 & $<0,024$ & 0,262 \\
$\mathbf{M n}$ & 70,115 & 705,899 & 352,3 & 912,4 & 719 & 388,3 & 598,8 & 316,934 & 75,9797 & 1030,04 \\
$\mathbf{F e O}$ & 0,23 & 3,06 & 1,47 & 3,29 & 2,82 & 0,85 & 2,33 & 0,4 & 0,25 & 3,77 \\
$\mathbf{L O I}$ & 0,44 & 0,73 & 1 & 1,06 & 0,57 & 0,44 & 0,58 & 0,8 & 0,25 & 0,9 \\
\hline
\end{tabular}

En los diagramas de Harker (FIGURA 6) se observa una correlación lineal de los óxidos mayores versus el aumento de $\mathrm{SiO}_{2}$. Las rocas migmatíticas (en rojo) se localizan dentro del mismo tren de cristalización de los granitos, sugiriendo que hacen parte del mismo magmatismo y fraccionamiento de las rocas desde valores en $\mathrm{SiO}_{2}$ de $58,92 \%$ hasta $77,39 \%$ (tonalitas a granitos), con variaciones en las tendencias de los óxidos a medida que aumenta el contenido de $\mathrm{SiO}_{2}$. El decrecimiento en $\mathrm{MgO}, \mathrm{FeO}$ y $\mathrm{CaO}$ con el incremento de la $\mathrm{SiO}_{2}$, sería consistente con la remoción temprana de plagioclasa, y piroxeno; el incremento de $\mathrm{Na}_{2} \mathrm{O}$ y $\mathrm{K}_{2} \mathrm{O}$, se debe a que no son incorporados a los minerales que cristalizan y se conservan o concentran en el líquido residual; $\mathrm{Al}_{2} \mathrm{O}_{3}$ y $\mathrm{CaO}$ decrecen continuamente, esto puede ser interpretado especulando que la plagioclasa comenzó a cristalizar tomando tanto $\mathrm{Ca}$ como Al. El comportamiento de $\mathrm{Na}_{2} \mathrm{O}$ vs $\mathrm{SiO}_{2}$ muestra una dispersión de los datos y valores más bajos para las rocas migmatíticas acidas (granofels cuarzo feldespáticos).

De acuerdo con la clasificación de Middlemost (1984) las rocas granitoides de edad Pérmica son subalcalinas y se clasifican químicamente en los campos de las cuarzomonzodioritas, granodioritas y granitos (FIGURA 7A), concordando con la clasificación petrográfica. 

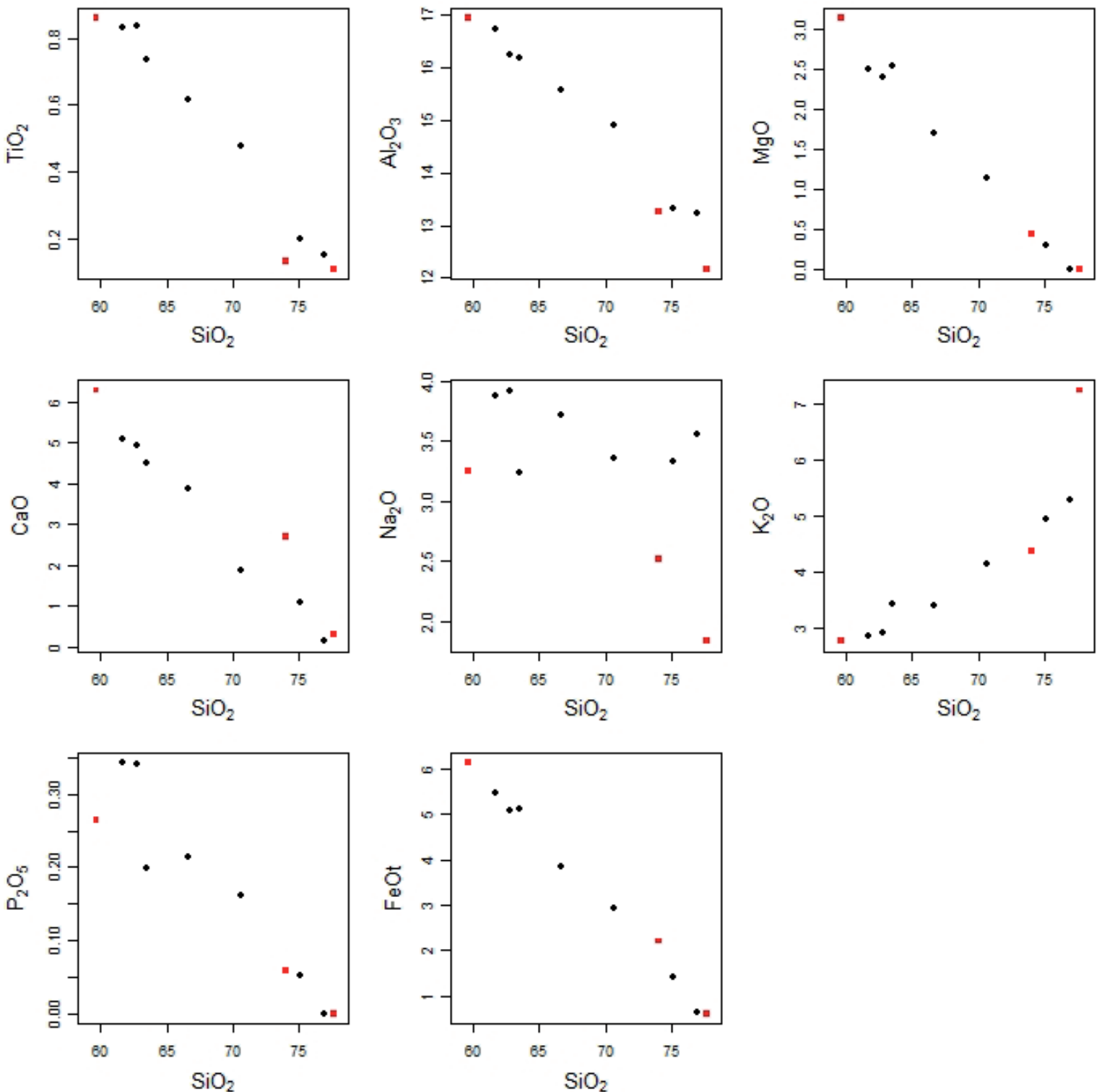

FIGURA 6. Diagramas de variación de Harker para rocas de edad Pérmica que afloran al occidente de La Plata y Pacarní - Huila, En negro rocas granitoides y en rojo rocas migmatíticas.

Los contenidos de $\mathrm{Na}_{2} \mathrm{O}+\mathrm{K}_{2} \mathrm{O}$ varían entre 5,94\% y $9,04 \%$, las muestras grafican dentro del campo de la serie calcoalcalina alta en K(FIGURA7B). Shand(1943)agrupó las rocas ígneas en base al contenido molar total de álcalis versus contenido de alúmina; obteniendo para las rocas Pérmicas que afloran al occidente de La Plata y Pacarní un carácter metaluminoso $\mathrm{Al}_{2} \mathrm{O}_{3}<\left(\mathrm{CaO}+\mathrm{Na}_{2} \mathrm{O}+\mathrm{K}_{2} \mathrm{O}\right)$ en las muestras 900723, 900732, 900739, 900800, 900802 y 900807 y peraluminoso $\mathrm{Al}_{2} \mathrm{O}_{3}>\left(\mathrm{CaO}+\mathrm{Na}_{2} \mathrm{O}+\mathrm{K}_{2} \mathrm{O}\right)$ para las muestras 900724, 900729, 900770 y 900806 (FIGURA 8A). En el grafico modificado por Villeseca et al. (1988) las rocas se reparten en los campos peraluminoso y metaluminosos (FIGURA 8B), sin que exista correlación del tipo de serie con el tipo de roca, grado de diferenciación y alteración. El comportamiento de las rocas entre estos dos campos de aluminosidad es también reportada por Leal-Mejía (2011), Vinasco et al. (2006), y Cardona et al. (2010) en otros intrusivos de edad Pérmica que afloran a lo largo de la Cordillera Central y Sierra Nevada de Santa Marta.

Según el diagrama de discriminación de Marc et al. (1992) basado en el contenido de $\mathrm{Al}_{2} \mathrm{O}_{3} \mathrm{vs} \mathrm{MgO}$, todas las muestras grafican dentro del campo de los ortogneises (FIGURA 9), indicando un origen magmático para todas las rocas de edad Pérmica analizadas incluyendo las rocas con estructura migmatítica y todas dentro de un solo tren lineal. 


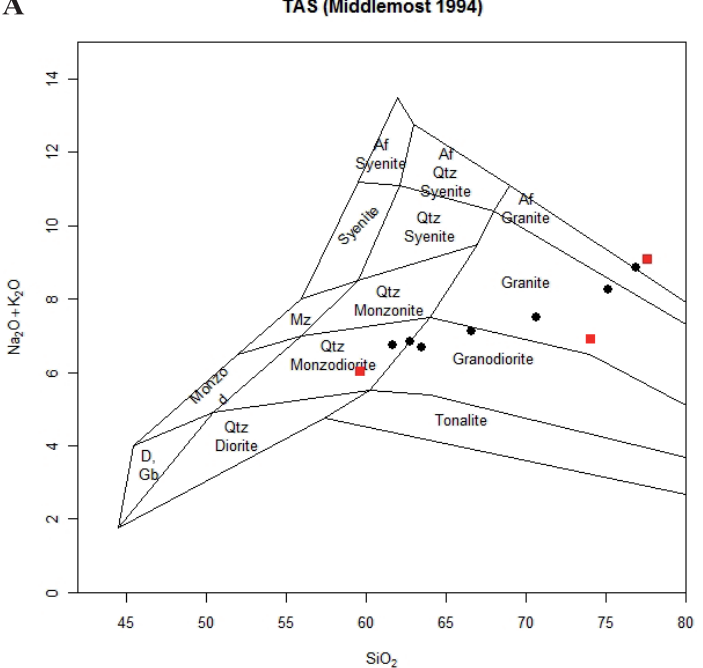

B

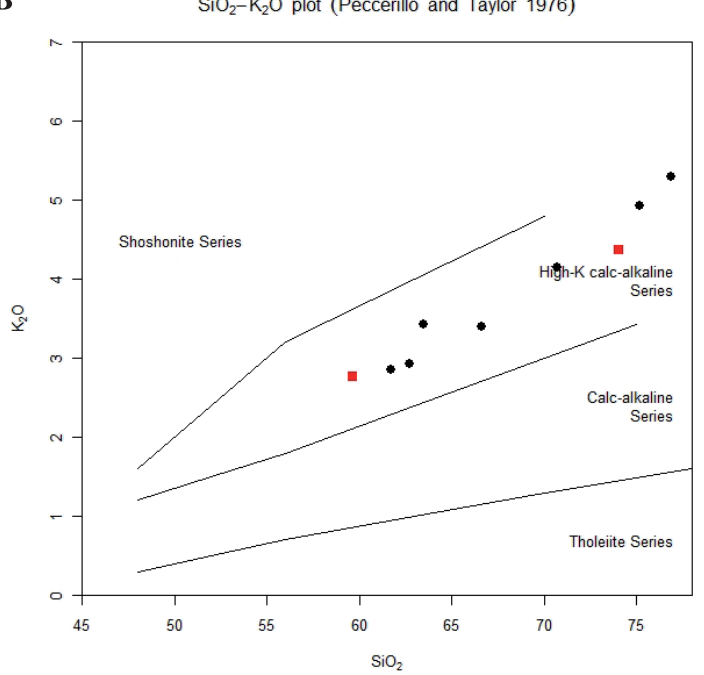

FIGURA 7. A. Clasificación química de rocas de edad Pérmica localizadas al occidente de La Plata y Pacarní - Huila, diagrama TAS de Middlemost (1984). B. Diagrama $\mathrm{K}_{2} \mathrm{O}$ vs $\mathrm{SiO}_{2}$ (Peccerillo and Taylor, 1976. En negro rocas granitoides y granitos y en rojo rocas migmatíticas.

A

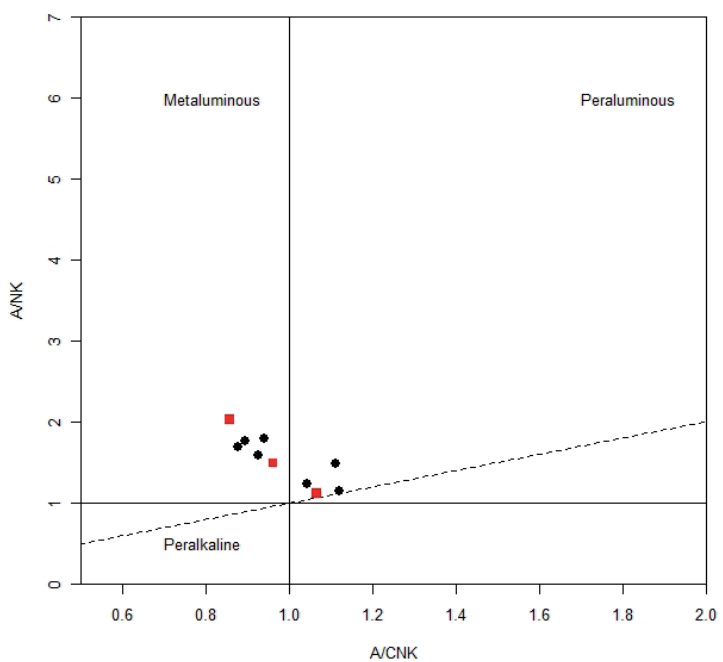

B

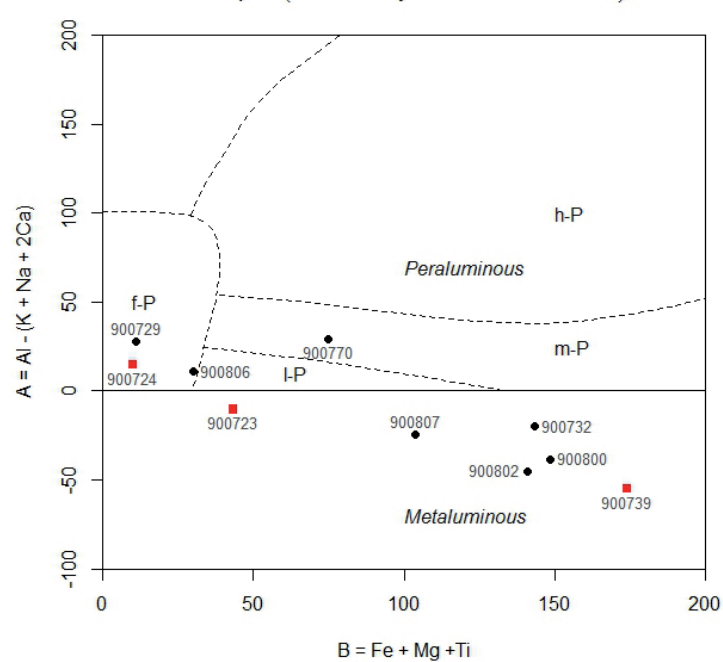

FIGURA 8. A. Diagrama de alcalinidad-aluminosidad (Shand, 1943) para rocas de edad Pérmica localizadas al occidente de La Plata y Pacarní - Huila. B. Diagrama propuesto por Debon and Le Fort (1983) modificado por Villaseca et al. (1998) con los campos de varios tipos de rocas peraluminosas, $1-\mathrm{P}=$ peraluminosa baja; $\mathrm{mP}$-peraluminosa moderada; h-P peraluminosa alta y f-P peraluminosa félsica. En negro rocas granitoides y en rojo rocas migmatíticas.

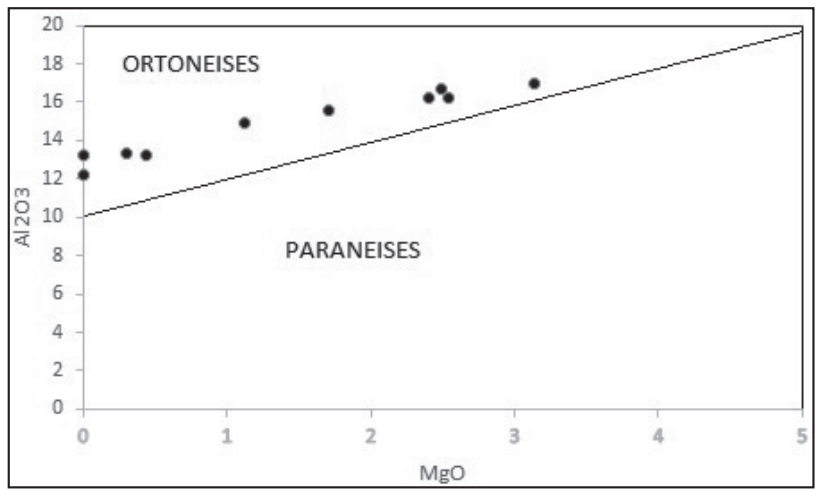

FIGURA 9. Diagrama de discriminación de protolito (Marc et al., 1992), para migmatitas, granitoides y granitos de edad Pérmica localizados al occidente de los municipios de La Plata y Pacarní - Huila. 
Caracterización petrográfica, geoquímica y geocronología de rocas granitoides Pérmicas al occidente de La Plata y Pacarní-Huila, Valle Superior del Magdalena-Colombia

\section{Elementos Traza y Tierras Raras}

En la TABLA 3 se presentan los resultados de los análisis (10) rocas de edad Pérmica localizadas al occidente de químicos de elementos Traza y Tierras Raras para diez La Plata y Pacarní - Huila.

TABLA 3. Resultados de elementos Traza y Tierras Raras para rocas de edad Pérmica localizadas al occidente de La Plata y Pacarní - Huila.

\begin{tabular}{|c|c|c|c|c|c|c|c|c|c|c|c|c|}
\hline $\begin{array}{c}\text { IGM } \\
\text { No. } \\
\text { CAMPO }\end{array}$ & $\begin{array}{r}900770 \\
\text { GR-6655 }\end{array}$ & 900732 & MIA-517 & MIA-518B & MIA-527 & 900729 & 900807 & 900739 & 900723 & 900724 & \multicolumn{2}{|c|}{$\begin{array}{c}\text { Limite } \\
\text { detección }\end{array}$} \\
\hline $\mathbf{L i}$ & 12,96 & 15,56 & 18,39 & 33,25 & 35,27 & 0,46 & 32,57 & 21,27 & 1,3 & 0,69 & 0,5 & ppm \\
\hline $\mathbf{B e}$ & 3,88 & 1,76 & 3,3 & 3,2 & 4,08 & 2,29 & 4,18 & 2 & 1,78 & 0,69 & 0,1 & ppm \\
\hline Sc & 9,04 & 16,53 & 17,19 & 16,14 & 3,7 & 2,43 & 12,49 & 20,75 & 4,97 & 0,34 & 0,1 & ppm \\
\hline $\mathbf{V}$ & 49,4 & 112,03 & 112,8 & 98,8 & 9 & 20,23 & 61,9 & 145,64 & 36,88 & 19,87 & 0,2 & $(\mathrm{mg} / \mathrm{Kg})$ \\
\hline $\mathrm{Cr}$ & 21,87 & 13,3 & 20,86 & 21,84 & 10,45 & 1,58 & 22,67 & 17,19 & 19,84 & 1,18 & 0,5 & ppm \\
\hline Co & 16,05 & 20,83 & 20,84 & 20,96 & 9,91 & 8,77 & 16,16 & 21,84 & 18,51 & 7,75 & 0,8 & ppm \\
\hline $\mathrm{Ni}$ & 8,51 & 17,91 & 10,81 & 12,46 & 2,9 & 0,89 & 10,31 & 18,01 & 11,68 & 0,39 & 0,5 & ppm \\
\hline $\mathrm{Cu}$ & 6,72 & 41,97 & 37,05 & 26 & 4,6 & 2,33 & 12,57 & 8,37 & 71,04 & 8,05 & 1 & ppm \\
\hline $\mathbf{Z n}$ & 62,01 & 75,12 & 103,8 & 78,98 & 28,25 & 11,62 & 74,98 & 128,53 & 37,6 & 11,88 & 4 & ppm \\
\hline Ga & 22,99 & 19,44 & 24,45 & 23,02 & 14,95 & 14,78 & 22,26 & 21,66 & 13,92 & 11,84 & 0,2 & ppm \\
\hline $\mathbf{R b}$ & 166,24 & 136,23 & 106,14 & 93,71 & 217,68 & 181,49 & 142,39 & 106,86 & 142,78 & 190,53 & 0,2 & ppm \\
\hline $\mathrm{Sr}$ & 413,08 & 509,07 & 780,9 & 724,88 & 157,12 & 48,98 & 592,08 & 685,75 & 390,44 & 250,79 & 1 & ppm \\
\hline $\mathbf{Y}$ & 19,29 & 19,68 & 21,19 & 18,88 & 19,98 & 83,18 & 22,63 & 15,5 & 7,44 & 6,56 & 0,1 & ppm \\
\hline Cd & 0,15 & 0,12 & 0,14 & 0,14 & 0,12 & 0,08 & 0,1 & 0,16 & 0,09 & 0,09 & 0,1 & ppm \\
\hline In & 0,03 & 0,06 & 0,05 & 0,05 & 0,01 & 0,01 & 0,04 & 0,05 & 0,07 & 0,01 & 0,01 & ppm \\
\hline Cs & 5,49 & 5,05 & 3,32 & 2,62 & 4,17 & 2,23 & 3,22 & 3,26 & 3,21 & 5,29 & 0,1 & ppm \\
\hline $\mathbf{B a}$ & 816,96 & 754,58 & 1205,15 & 1165,91 & 748,4 & 217,16 & 1047,58 & 917,29 & 683,79 & 253,81 & 1 & ppm \\
\hline La & 41,36 & 30,37 & 36,26 & 35,66 & 34,3 & 36,84 & 44,65 & 25,95 & 8,17 & 29,83 & 0,1 & ppm \\
\hline $\mathrm{Ce}$ & 76,33 & 61,62 & 70,54 & 70,67 & 65,42 & 80,29 & 82,93 & 50,93 & 16,72 & 50,34 & 0,1 & ppm \\
\hline Pr & 8,98 & 7,57 & 9,04 & 8,57 & 7,08 & 7,86 & 9,91 & 6,22 & 1,97 & 5,05 & 0,1 & ppm \\
\hline Nd & 28,2 & 29,18 & 32,78 & 32,51 & 21,99 & 27,32 & 36,67 & 24,92 & 7,11 & 14,79 & 0,1 & ppm \\
\hline Sm & 6,02 & 5,24 & 7,02 & 6,46 & 4,37 & 4,35 & 6,84 & 4,72 & 1,37 & 1,91 & 0,01 & ppm \\
\hline $\mathbf{E u}$ & 1,49 & 1,69 & 2,43 & 2,35 & 1,02 & 0,44 & 2,03 & 1,88 & 0,72 & 0,47 & 0,01 & ppm \\
\hline Gd & 5,4 & 4,91 & 6,36 & 5,88 & 4,23 & 4,06 & 6,25 & 4,36 & 1,3 & 1,99 & 0,01 & ppm \\
\hline $\mathbf{T b}$ & 0,76 & 0,73 & 0,89 & 0,78 & 0,62 & 0,49 & 0,9 & 0,63 & 0,19 & 0,19 & 0,01 & ppm \\
\hline Dy & 3,94 & 3,63 & 4,58 & 3,99 & 3,41 & 2,08 & 4,5 & 2,95 & 1 & 0,83 & 0,01 & ppm \\
\hline Ho & 0,8 & 0,7 & 0,9 & 0,79 & 0,71 & 0,39 & 0,88 & 0,58 & 0,21 & 0,17 & 0,01 & ppm \\
\hline $\mathbf{E r}$ & 2,52 & 2,13 & 2,75 & 2,44 & 2,28 & 1,22 & 2,76 & 1,7 & 0,67 & 0,61 & 0,01 & ppm \\
\hline $\mathbf{T m}$ & 0,36 & 0,29 & 0,37 & 0,33 & 0,34 & 0,17 & 0,39 & 0,22 & 0,1 & 0,09 & 0,01 & ppm \\
\hline $\mathbf{Y b}$ & 2,57 & 1,92 & 2,5 & 2,3 & 2,42 & 1,27 & 2,6 & 1,41 & 0,73 & 0,65 & 0,01 & ppm \\
\hline Lu & 0,39 & 0,28 & 0,38 & 0,36 & 0,39 & 0,2 & 0,41 & 0,22 & 0,12 & 0,11 & 0,01 & ppm \\
\hline Tl & 0,78 & 0,61 & 0,5 & 0,38 & 0,99 & 0,74 & 0,6 & 0,59 & 0,66 & 0,95 & 0,01 & ppm \\
\hline $\mathbf{P b}$ & 18,84 & 16,19 & 18,4 & 13,29 & 16,05 & 9,58 & 16,12 & 20,83 & 21,35 & 38,6 & 2 & ppm \\
\hline Th & 38,77 & 18,96 & 11,05 & 13,79 & 25,33 & 30,3 & 21,26 & 11,58 & 9,69 & 31,63 & 0,1 & ppm \\
\hline $\mathbf{U}$ & 8,46 & 4,36 & 3 & 4 & 7,6 & 2,66 & 5,47 & 1,57 & 4,81 & 5,2 & 0,01 & ppm \\
\hline Nb & 10,6 & 10 & 9,1 & 9,3 & 9 & 15,9 & 10,9 & 7,1 & 3,1 & 5,2 & 2 & $(\mathrm{mg} / \mathrm{Kg})$ \\
\hline $\mathbf{W}$ & 29,2 & & 18,4 & 32,9 & 31,8 & & 22,8 & & & & 8 & $(\mathrm{mg} / \mathrm{Kg})$ \\
\hline $\mathbf{Z r}$ & 142,4 & 162,87 & 190,4 & 155,4 & 115,4 & $<130$ & 173,9 & 177,67 & 244,3 & $<130$ & 2 & $(\mathrm{mg} / \mathrm{Kg})$ \\
\hline
\end{tabular}


El diagrama de elementos de las Tierras Raras (REE) normalizado a condrito según los valores de McDonough and Sun, (1995) (FIGURA 10), muestra para las rocas granitoides un enriquecimiento en tierras raras livianas (LREE) de más de 100 veces respecto al valor del condrito, con un patrón homogéneo que se va empobreciendo progresivamente hacia las tierras raras pesadas (HREE) y un tren horizontal entre disprosio (Dy) y lutecio (Lu), comportamiento normal para rocas generadas en ambientes de subducción (Wilson, 1989). Las muestras de granitos presentan una tendencia paralela; la muestra 900729GR-6643 tiene una fuerte anomalía negativa de $\mathrm{Eu}$, probablemente debida a fraccionamiento de la plagioclasa en el magma, permitiendo que el $\mathrm{Eu}^{+3}$ cambie su estado de oxidación a $\mathrm{Eu}^{+2}$. Esto facilita que se incorpore preferentemente plagioclasa en la estructura, que al fraccionarse en las primeras etapas de diferenciación del magma deja un líquido empobrecido en $\mathrm{Eu}$ (Winter, 2001).

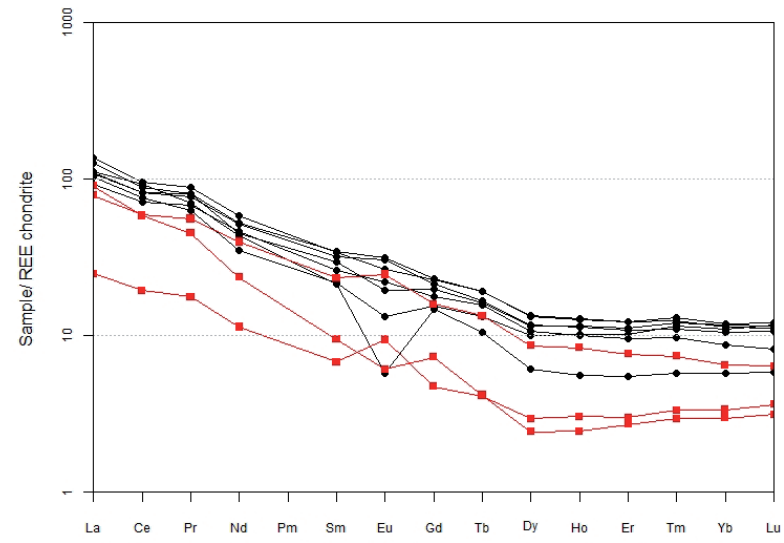

FIGURA 10. Diagrama de REE normalizado respecto al condrito (McDonough and Sun, 1995) para rocas de edad Pérmica localizadas al occidente de La Plata y Pacarní - Huila. En negro rocas granitoides y en rojo rocas migmatíticas.

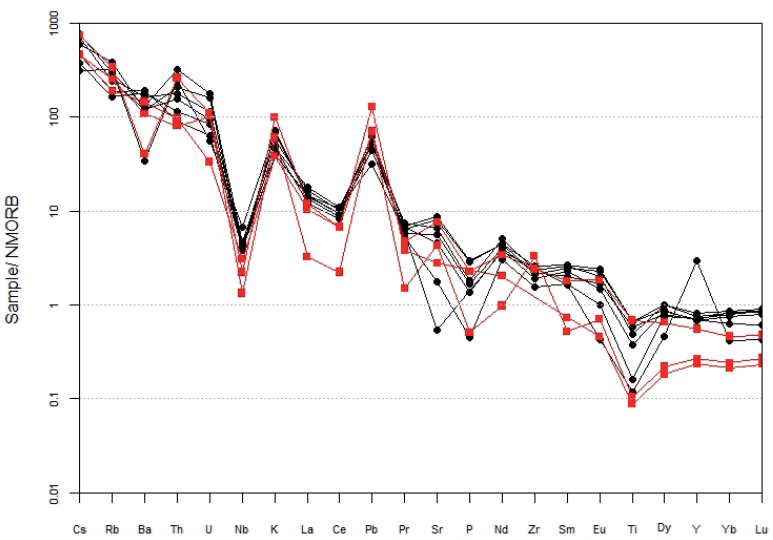

La ausencia de anomalía de Eu en la mayoría de las muestras a una leve anomalía positiva de Eu se atribuye a que no se dio fraccionamiento de la plagioclasa. Por otra parte, las rocas migmatíticas (muestras 900723 y 900739) presentan patrones paralelos al de los granitos, más empobrecidos en tierras raras pesadas y livianas con relación al valor del condrito en la muestra IGM-900739, sugiriendo la posibilidad de que los granitos y las rocas con estructura migmatítica se formaron en un mismo evento ígneo y únicamente la muestra IGM-900724 presenta patrón diferente que podría sugerir un origen diferente.

El diagrama multielemental de elementos trazas (Sun and McDonough, 1989 en Pearce, 2014) (FIGURA 11), muestra anomalía negativa de los elementos inmóviles $\mathrm{Nb}$, Ti y $\mathrm{P}$ que pueden corresponder a separación de fases minerales accesorias como titanita, rutilo y apatito (Winter, 2001), donde el $\mathrm{Nb}$ se comporta geoquímicamente similar al Ti. Las anomalías negativas de $\mathrm{Nb}$, Ti y $\mathrm{P}$ son características de arcos magmáticos relacionados a ambientes de subducción, con empobrecimiento progresivo hacia los elementos pesados, además, presentan anomalía negativa de $\mathrm{Nb}$ con respecto al $\mathrm{Th}$ y $\mathrm{Ce}$, signatura geoquímica típica de magmas originados en ambientes tectónicos relacionados a arcos (Pearce, 1996), con patrón subparalelo para la mayoría de las muestras. Los elementos traza más móviles (LILE) tienen concentraciones mayores que el N-MORB, mientras los elementos traza menos móviles están por debajo del N-MORB. Las muestras de migmatitas 900723 y 900724 y del granito 900729 tienen un tren de elementos traza inmóviles más empobrecido que el patrón general de los granitos, con dispersión de valores entre Sr y Lu, La muestra 900729 presenta una anomalía positiva de $\mathrm{Y}$, que no ocurre en las demás rocas, con un valor anormalmente alto que podría indicar contaminación externa de la muestra.

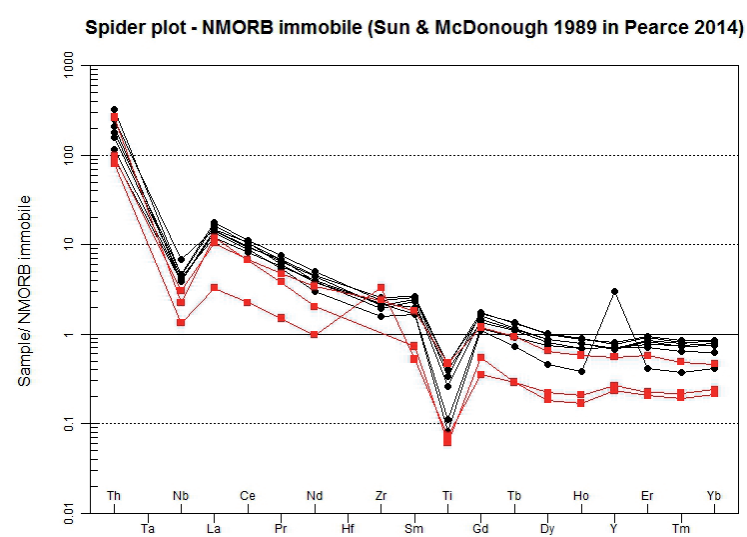

FIGURA 11. Diagrama multielemental normalizado al N-MORB (Sun and McDonough, 1989), N-MORB (Sun and McDonough, 1989, en Pearce, 2014). En negro rocas granitoides y en rojo rocas migmatíticas. 
Los diagramas geoquímicos de discriminación tectónica (Pearce et al., 1984) vinculan al magmatismo de las rocas de edad Pérmica de los alrededores de La Plata y Pacarní - Huila a un ambiente de arco relacionado a márgenes continentales activas. Las rocas grafican dentro del campo de los granitos de arco volcánico, con dispersión de las muestras de granofels que se apartan de los granitos con contenidos menores de $\mathrm{Y}+\mathrm{Nb}$, dos rocas alcanzan el límite de los granitos sin-colisionales (FIGURA 12).

En el diagrama de Pearce (2008) las muestras de edad Pérmica se localizan dentro del campo de los arcos volcánicos por encima del campo de las rocas de corteza oceánica- MORB-OIB, con relaciones altas de Th/ $\mathrm{Yb}$ y $\mathrm{Nb} / \mathrm{Yb}$ (FIGURA 13A) sin diferenciación entre

$\mathbf{A}$

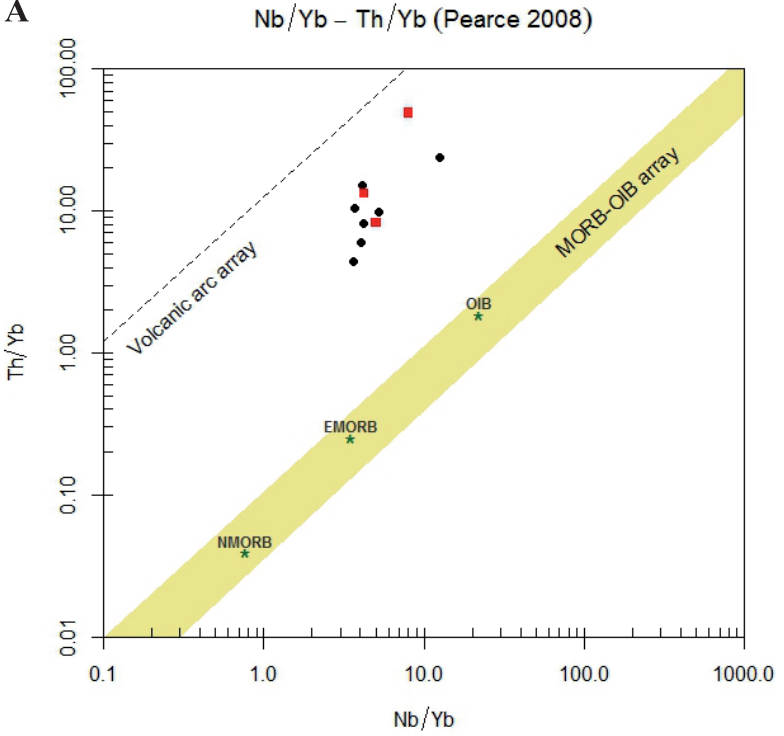

migmatitas y granitos. En general las bajas relaciones $\mathrm{Rb} / \mathrm{Zr}$ hacen que las rocas se localicen en el campo de los granitos de arco volcánico y granitos tardíos o post colisionales (Harris et al., 1986) (FIGURA 13B).
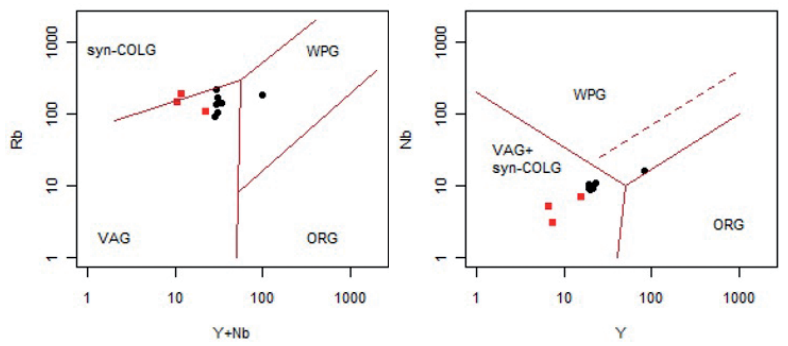

FIGURA 12. Diagramas de ambiente de discriminación tectónica de Pearce (1984) para muestras de edad Pérmica localizadas al occidente de La Plata y Pacarní - Huila.
B

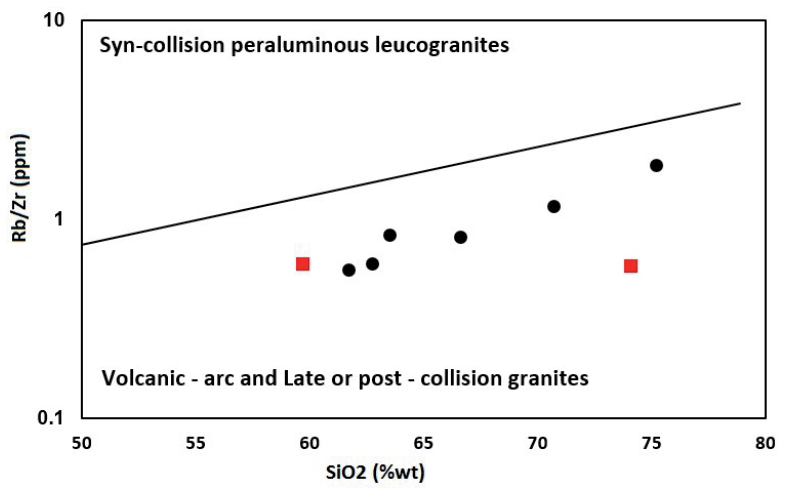

FIGURA 13. Diagrama de discriminación para rocas de edad Pérmica al occidente de La Plata y Pacarní - Huila. En negro muestras granitoides y en rojo muestras migmatíticas. A. Diagrama de Pearce (2008) para rocas de arco y rocas de corteza oceánica: Manto empobrecido N-MORB, Manto enriquecido E-MORB, Basaltos de Islas Oceánicas (OIB). B. Diagrama de Harris et al. (1986).

\section{GEOCRONOLOGÍA U-Pb}

Se presentan los resultados de la geocronología U-Pb LAM-ICP-MS en circones realizadas en los laboratorios de la Universidad Autónoma de México (UNAM) y el Servicio Geológico Colombiano (SGC). Los resultados isotópicos se presentan en la TABLA 4 y las coordenadas de las muestras analizadas se presentan en datum Magna Colombia Bogotá. Las edades se obtuvieron a partir de 7 muestras (FIGURA 1), clasificadas como granitos y migmatítas, en estas últimas el muestreo incluyó el leucosoma y el melanosoma.
Las rocas analizadas corresponden a cuarzomonzonita (MIA-531, n=42), monzogranitos (GR-6643, n=21; GR$6655 \mathrm{n}=46$; MIA-516, n=32) y granofels de Qz-Pl-Kfs (GR-6631, n=33, GR-6632, n=30 y JGB-373, n=26).

Las imágenes de catodoluminiscencia revelan una estructura interna general para circones de granitos y migmatitas de tipo concéntrico, dada por zonamientos y núcleos más oscuros de aspecto homogéneo (FIGURA 14), afín con la estructura típica de circones magmáticos; si el crecimiento fuera metamórfico los circones debería ser más homogéneos y no zonados. Las muestras GR- 
6631 y GR-6632 (granofels) presentan circones finos prismáticos algunos con terminaciones redondeadas, tienen núcleos, alrededor de los cuales se desarrollan zonamientos oscilatorios y bordes luminiscentes. La muestra JGB-373 corresponde a un granofels de composición granítica; los circones son principalmente mayores de $150 \mu \mathrm{m}$, bajo catodoluminiscencia son euhedrales, se observan núcleos más oscuros similares a los circones de granitos y bordes oscilatorios de aspecto magmático. La muestra GR-6643 los circones son generalmente alargados, con terminaciones a veces redondeadas, oscuros en luz reflejada y bajo CL se caracterizan por tener núcleo oscuro, alrededor de los cuales se desarrollan bordes más luminiscentes. Las muestras de monzogranitos (GR-6655, MIA-516 y MIA-531) presentan circones prismáticos cortos y algunos alargados, euhedrales a subhedrales de tamaños entre 50 y $130 \mu \mathrm{m}$; bajo CL muestran zonamiento oscilatorio con algunos núcleos oscuros.

La edad promedio y clasificación petrográfica se presenta en la TABLA 4, en la FIGURA 15 y FIGURA 16.

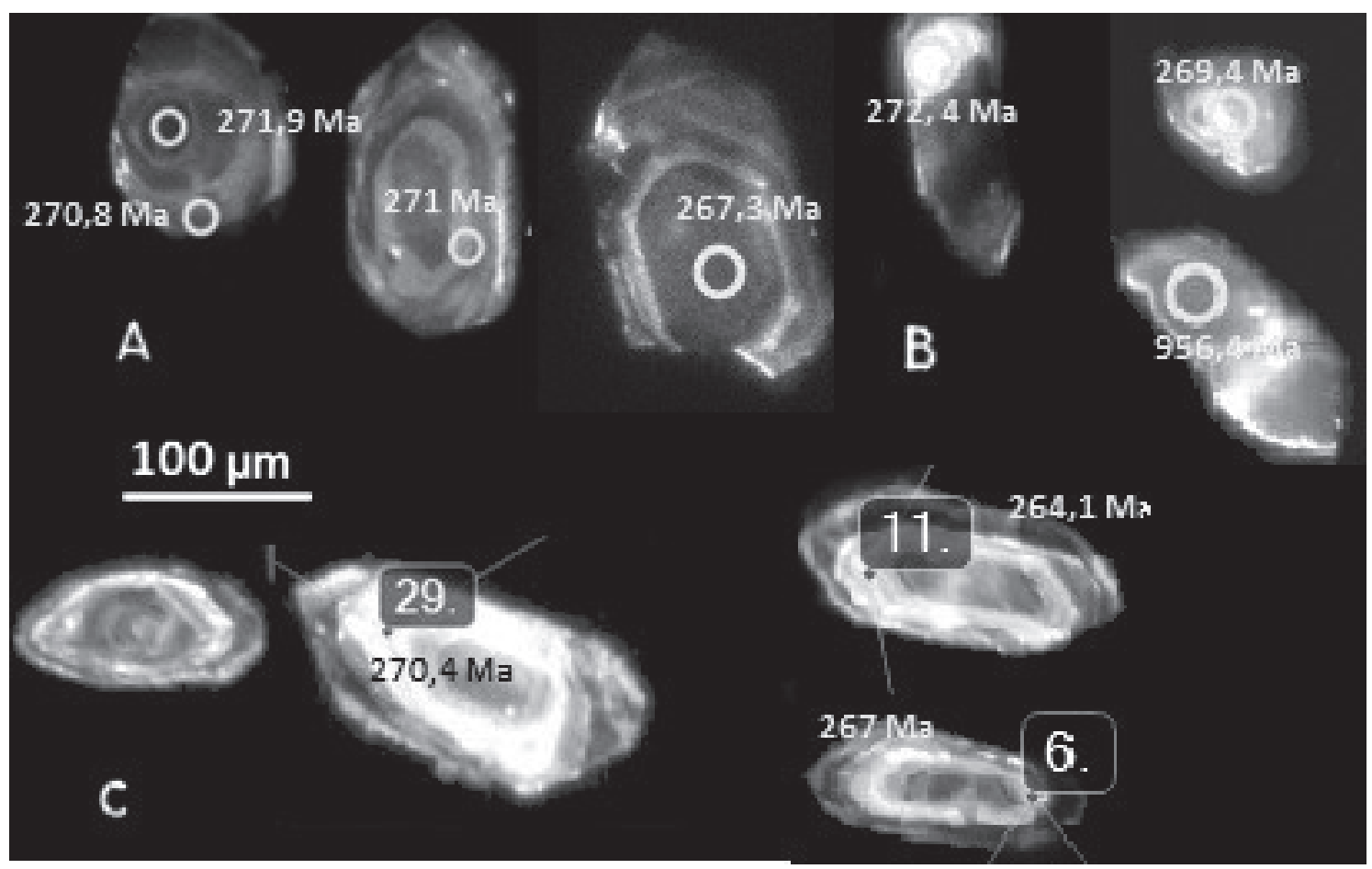

FIGURA 14. Formas de cristales de circón para rocas de edad Pérmica al occidente de La Plata y Pacarní - Huila. A. y B. Circones de granitos (GR-6655 y MIA-531). C. Circones de la migmatita (JGB-373).

TABLA 4. Resumen de edades U-Pb en circón para rocas de edad Pérmica localizadas al occidente de La Plata y Pacarní - Huila.

\begin{tabular}{ccccccc}
\hline IGM & $\begin{array}{c}\text { N } \\
\text { CAMPO }\end{array}$ & $\mathbf{N}$ & $\mathbf{W}$ & CLASIFICACIÓN & $\begin{array}{c}\text { Edad U-Pb } \\
\text { (Ma) }\end{array}$ & Edades heredadas \\
\hline 900739 & JGB-373 & 764341 & 795222 & $\begin{array}{c}\text { Granofels de Qtz-Pl- } \\
\text { Kfs-Bt con Cpx }\end{array}$ & $268,3 \pm 2,0$ & $(960 \pm 100, \mathrm{n}=1) ;(1140 \pm 130, \mathrm{n}=1$ \\
900770 & GR-6655 & 739480 & 769044 & Monzogranito & $269,0 \pm 3,0$ & $841,43 \pm 64,1, \mathrm{n}=1$ \\
& MIA-516 & 738376 & 772645 & Granito & $270,0 \pm 2,7$ & $(297 \pm 11, \mathrm{n}=2) ;(309,55 \pm 13,7, \mathrm{n}=1)$ \\
900807 & MIA-531 & 718450 & 767031 & Cuarzomonzonita & $272,0 \pm 6,8$ & $(903 \pm 79, \mathrm{n}=3)$ \\
900723 & GR-6631 & 754825 & 789810 & $\begin{array}{c}\text { Granofels de Qtz-P1l- } \\
\text { Kfs (monzogranito) }\end{array}$ & $273,2 \pm 4,1$ & $\left(\begin{array}{c}(315 \pm 15, \mathrm{n}=6) ;(393 \pm 14, \mathrm{n}=2) ;(534 \pm 34, \mathrm{n}=5), \\
(972, \mathrm{n}=2) ;(1401 \pm 50, \mathrm{n}=2) ;(1781 \pm 66 \mathrm{n}=5)\end{array}\right.$ \\
900724 & GR-6632 & 755397 & 789376 & $\begin{array}{c}\text { Granofels de qz-pl-kfs } \\
\text { (sienogranito) }\end{array}$ & $277,9 \pm 2,1$ & $(295,8 \pm 3,7, \mathrm{n}=3) ;(314,9 \pm 4,5, \mathrm{n}=2)$ \\
900729 & GR-6643 & 785328 & 811713 & Monzogranito & $274,8 \pm 2,3$ & $(291,3 \pm 3,1, \mathrm{n}=4) ;(304 \pm 6,5, \mathrm{n}=1)$ \\
\hline
\end{tabular}



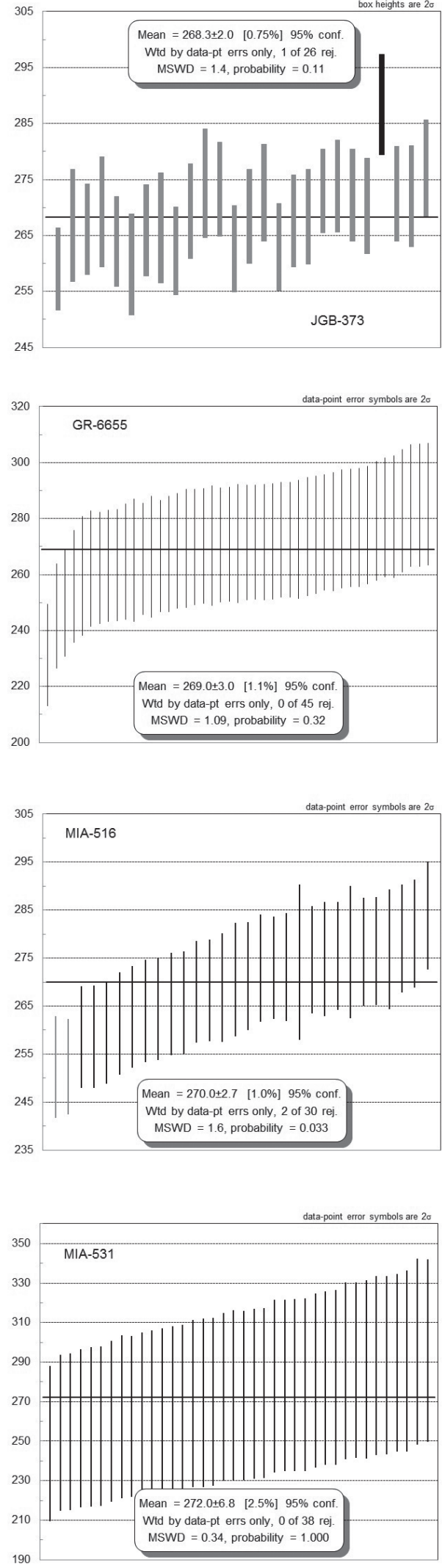
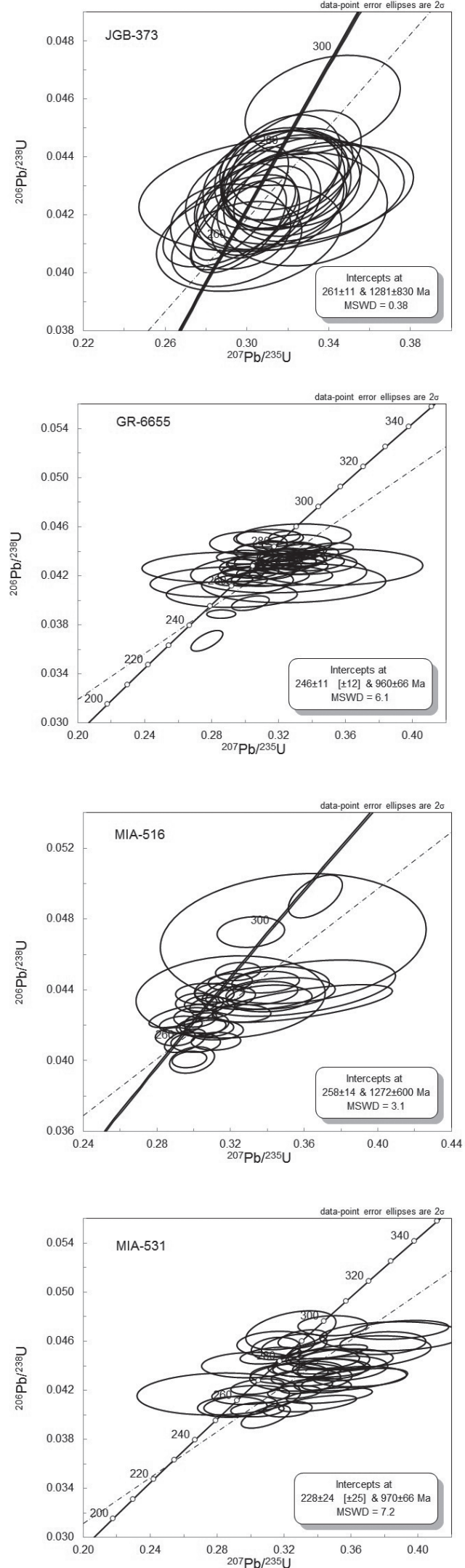

FIGURA 15. Resultados geocronológicos U-Pb en circones de rocas Pérmicas del occidente de La Plata y Pacarní - Huila. 
Los circones presentan zonamientos oscilatorios que sugieren un origen ígneo, con núcleos homogéneos de color más oscuro, que en algunos casos corresponden a núcleos heredados (Belousova et al., 2006). La relación $\mathrm{Th} / \mathrm{U}$ en las rocas graníticas y migmatíticas está en el rango de 0,1 a 1 , relación alta que sugieren un origen ígneo tanto para los núcleos heredados como para los bordes zonados (Rubatto, 2002) (FIGURA 15).

Los datos obtenidos en este estudio se interpretan como edad de cristalización de las rocas con edades Pérmicas, consistente con el dato previo reportado por Leal-Mejía, (2011) por el método U-Pb LA-MCICP-MS en circón de $274,8 \pm 4,6 \mathrm{Ma}$, para una tonalita localizada al occidente de La Plata, con una edad heredada de $750 \mathrm{Ma}$. Son comunes los granos de circón con núcleos heredados de edades Mesoproterozoicas para las rocas migmatíticas (rango de edades entre 960 a $1780 \mathrm{Ma}$ ) y Neoproterozoicas para las rocas graníticas.

La roca JGB-373A arroja una edad $\mathrm{U} / \mathrm{Pb}$ promedia ponderada de $268,3 \pm 2,0 \mathrm{Ma}$ a partir de 26 circones, con un MSWD $=1,4$, con un circón heredado de $960 \pm 100 \mathrm{Ma}$, y otro de $1140 \pm 130 \mathrm{Ma}$. Por su parte la muestra GR-6655 tiene una edad promedia ponderada de $269 \pm 3$ Ma a partir de 45 circones, con MSWD = 1,09 ; presenta tres circones $(n=3)$ discordantes que representan pérdida de plomo común (Schoene, 2014) y un circón heredado de $841,43 \pm 64,1$ Ma del Neo- proterozoico. La muestra MIA-516 tiene una edad promedia ponderada de $270,0 \pm 2,7$ Ma a partir de 32 circones, con un MSWD =1,6.

La roca MIA-531 tiene una edad $\mathrm{U} / \mathrm{Pb}$ promedio ponderada de $272,0 \pm 6,8$ a partir de 38 circones, con un $\mathrm{MSWD}=0,34$, y circones heredados con edad promedio de $903 \pm 79 \mathrm{Ma}(\mathrm{n}=3)$. La roca GR-6631 arrojó una edad promedio de $273,2 \pm 4,1$ Ma a partir de 10 circones, con un MSWD $=0,87$; presenta herencias más antiguas con registro de núcleos heredados de 315 $\pm 15(\mathrm{n}=6), 393 \pm 14$ Ma $(\mathrm{n}=2)$, $534 \pm 34 \mathrm{Ma}(\mathrm{n}=5), 972 \mathrm{Ma}(\mathrm{n}=2), 1401 \pm 50 \mathrm{Ma}(\mathrm{n}=2)$ y $1781 \pm 66 \mathrm{Ma}(\mathrm{n}=5)$.

La roca GR-6632 dio una edad promedia ponderada de $277,9 \pm 2,1$ Ma a partir de 22 circones con un MSWD $=2,5$, y edades heredadas de $295,8 \pm 3,7 \mathrm{Ma}(\mathrm{n}=3)$ y $314,9 \pm 4,5 \mathrm{Ma}(\mathrm{n}=2)$.
La edad promedio ponderada de la roca GR-6643 es de $274,8 \pm 2,3$ Ma a partir de 14 circones, con un MSWD $=1,9$, con edades heredadas de $291,3 \pm 3,1 \mathrm{Ma}(\mathrm{n}=4) \mathrm{y}$ $304 \pm 6,5 \mathrm{Ma}(\mathrm{n}=1)$.

Los núcleos de circones heredados presentan relación $\mathrm{Th} / \mathrm{U}>0,1$ y cercanas a 1 que sugieren origen ígneo (Rubatto, 2002).

\section{GEOQUÍMICA DE ELEMENTOS TRAZA EN CIRCONES}

El análisis de ICP-MS de los circones enviados al laboratorio de geocronología de la UNAM determinó la abundancia de los elementos traza en cada circón, los valores de REE se normalizaron a condrito (McDonough and Sun, 1995) y se calcularon las relaciones Pm* y Tm* para cada uno de ellos.

Se analizaron los circones de las rocas migmatíticas (GR-6631, GR-6632, JGB-373A) y granítica (GR6643). Para todas las muestras los valores de $\mathrm{Ti}$ son semejantes y varía entre 27,92 ppm (GR-6631), $27,87 \mathrm{ppm}$ (GR-6632) y 16,34 ppm (JGB-373A) para las migmatitas y de $16,57 \mathrm{ppm}$ para los granitos (GR-6643). Ambos grupos de rocas siguen un patrón de fraccionamiento que aumenta hacia las tierras raras pesadas (HREE) (FIGURA 16), con valores levemente mayores a 10000 veces el condrito (McDonough and Sun, 1995) para los circones de las rocas graníticas y la roca granofélsica (GR6632) y valores menores de 10000 para las rocas migmatíticas, reflejando posiblemente en este último grupo de rocas la influencia del piroxeno que se encuentra en cantidades modales y donde se concentran las HREE.

Los circones de rocas graníticas y migmatíticas Pérmicas que afloran al occidente de La Plata y Pacarní - Huila, tienen anomalías positivas de $\mathrm{Ce}$ y anomalía negativa de $\mathrm{Eu}$ moderadamente pronunciada, es una característica que tienen todos los circones de origen ígneo (Hoskin and Schaltegger, 2003), donde la presencia de anomalía positiva de Ce sugiere un magma oxidado mientras la coexistencia con la anomalía negativa de Eu sugiere condiciones reducidas, siendo estas anomalías comunes en granitoides ígneos de Tipo I, A y S (Wang et al., 2012) (FIGURA 17). 

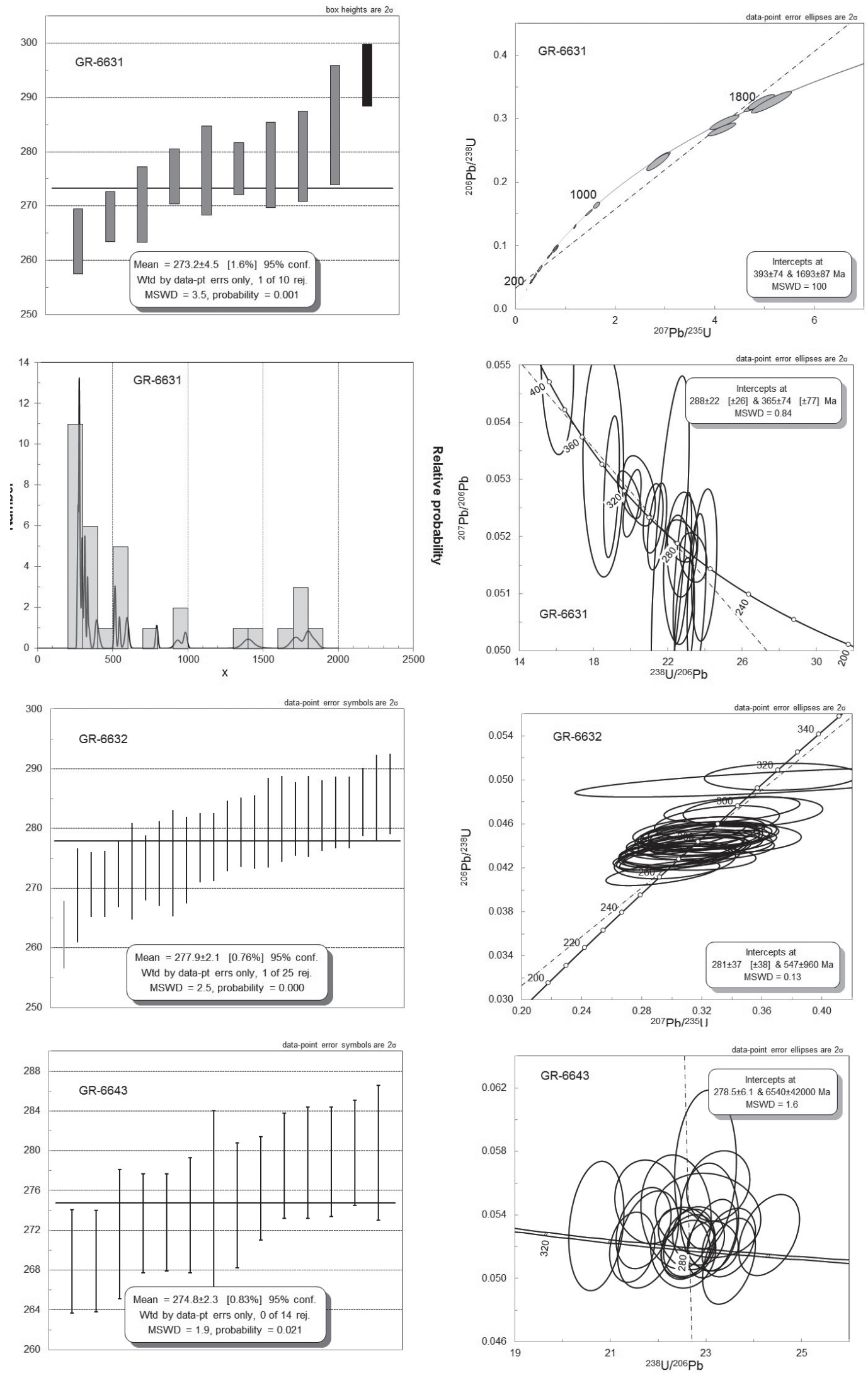

FIGURA 16. Resultados geocronológicos U-Pb de muestras de edad Pérmica del occidente de La Plata y Pacarní - Huila. 

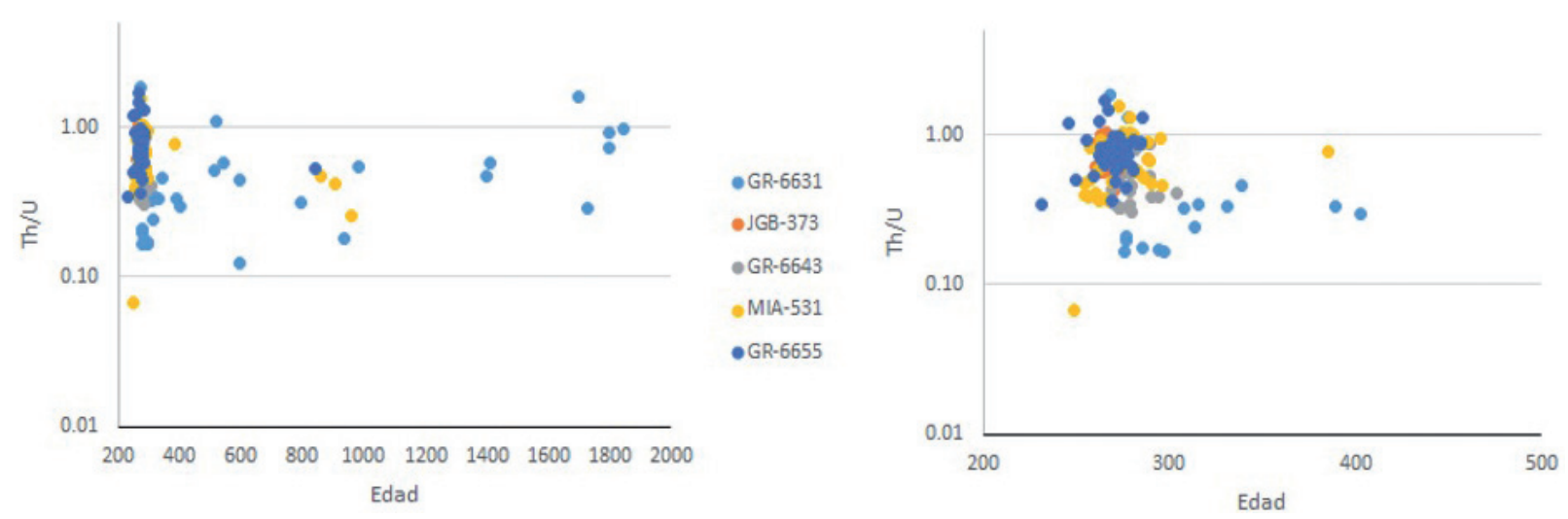

FIGURA 17. Diagrama de relación Th/U vs Edad para cinco muestras de rocas de edad Pérmica al occidente de La Plata y Pacarní - Huila.

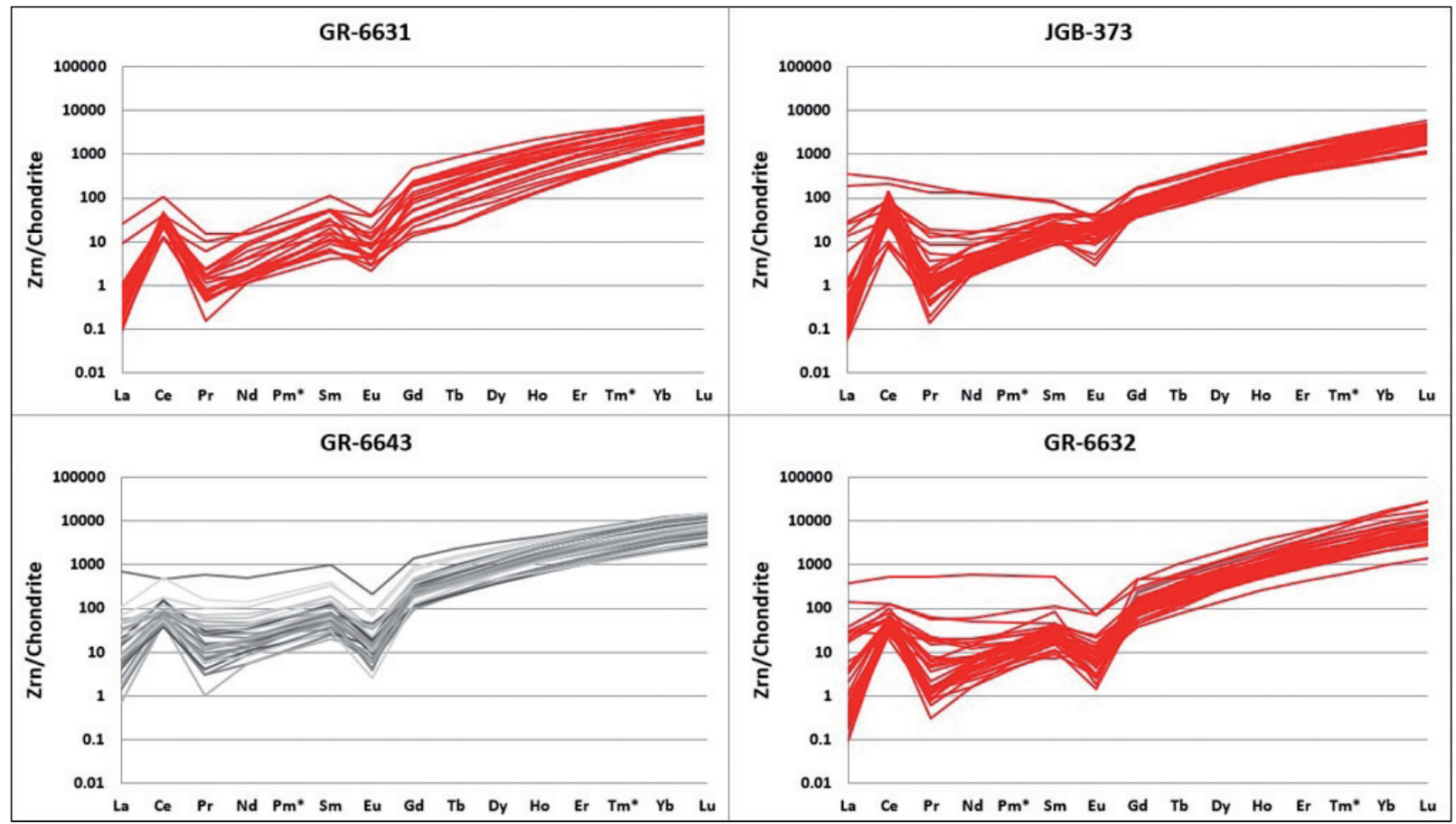

FIGURA 18. Diagrama REE con valores McDonough and Sun (1995) para rocas de edad Pérmica al occidente de La Plata y Pacarní - Huila. En rojo rocas migmatíticas y granofélsicas, en negro roca granítica.

Para discriminar entre granitoides de tipos I, A y S, Wang et al. (2012), indica diferencias en los contenidos de $\mathrm{Pb}$ y Th en circones. Los valores obtenidos en los circones de la muestra GR-6631 para $\mathrm{Pb}$ varían entre 16 y $101 \mathrm{ppm}$, Th entre 110 y 893 ppm, la relación $\mathrm{Th} / \mathrm{Pb}$ entre 2,6 y 17,2; las concentraciones de $\mathrm{Y}$ (260-3340 ppm) son parcialmente comparables a las concentraciones de circones de granitoides (5004534), con una anomalía negativa de $\mathrm{Eu}\left(\mathrm{Eu} / \mathrm{Eu}^{*}=\right.$ $0,04$ y 0,55 principalmente $>0,16)$ y valores de $(\mathrm{Lu})$ $\mathrm{N}$ en el rango entre 1756 y 7613 (normalizado al condrito de Sun and McDonough, 1989). Los circones de la muestra GR-6643 presentan contenidos de $\mathrm{Pb}$ entre 12,9 y 186 , Th entre 183 y $2250 \mathrm{ppm}$, la relación $\mathrm{Th} / \mathrm{Pb}$ varía de 6,5 a 20,2; las concentraciones de $\mathrm{Y}$ son de 1012 a $7620 \mathrm{ppm}$, con una anomalía negativa de $\mathrm{Eu}\left(\mathrm{Eu} / \mathrm{Eu}^{*}=0,02\right.$ a 0,27$)$ y valores de $(\mathrm{Lu})_{\mathrm{N}}$ en el rango entre 3028 y 14959 . Los circones de la muestra GR-6632 los contenidos de Pb varían entre 10,27 y 438,3 ppm; el Th entre 203,9 y 2481 ppm, la relación $\mathrm{Th} / \mathrm{Pb}$ va de 1,1 a 15,4, la concentración de $\mathrm{Y}$ varía entre 421 y 5880 ppm, con anomalía negativa de Eu $\left(\mathrm{Eu} / \mathrm{Eu}^{*}=0,02-0,38\right)$ y valores de $(\mathrm{Lu})_{\mathrm{N}}$ en el rango entre 1410 y 9841 en la mayoría de circones. Los 
circones de la muestra JGB-373 los contenidos de $\mathrm{Pb}$ varían entre 5,2 y $60,2 \mathrm{ppm}$; el Th entre 5,3 y 1170 ppm, la relación $\mathrm{Th} / \mathrm{Pb}$ entre 0,8 y 25,2 , el $\mathrm{Y}$ varía entre 397 y 1860 ppm, con anomalía negativa de $\mathrm{Eu}$ $\left(\mathrm{Eu} / \mathrm{Eu}^{*}=0,11-0,71\right)$ y valores de $(\mathrm{Lu})_{\mathrm{N}}$ en el rango entre 1044 y 4898.

Los Granitos de Tipo I según Wang et al. (2012), presenta contenidos de $\mathrm{Pb}<25 \mathrm{ppm}$, Th entre 34 y $1746 \mathrm{ppm}, \mathrm{Th} / \mathrm{Pb}$ de 14 a $130,(\mathrm{Lu})_{\mathrm{N}}$ entre 1330 y 15574, anomalía negativa de $\mathrm{Eu}\left(\mathrm{Eu} / \mathrm{Eu}^{*}=0,14-0,34\right)$ y concentraciones de Y entre 493 y 7833 ppm. Los valores propuestos por Wang et al. (2012) para los granitoides de Tipo A son: contenidos de $\mathrm{Pb}$ entre 5-25 ppm, Th entre 87 y $458 \mathrm{ppm}$, con anomalía negativa de $\mathrm{Eu}\left(\mathrm{Eu} / \mathrm{Eu}^{*}=0,003\right.$ a 0,29$)$ y valores de $(\mathrm{Lu})_{\mathrm{N}}$ entre 2020 y 5507, con concentraciones de Y de 1001 a 3361 ppm.

Al comparar los valores de elementos trazas en circones y algunas relaciones contra los valores propuestos por Wang et al. (2012) para granitoides de tipos I, A y S, no se observa una clara discriminación de los datos. En la FIGURA 19 se grafican los contenidos de $\mathrm{Pb}$ y Th de los circones de las cuatro muestras de edad Pérmica recolectadas al occidente de La Plata y Pacarní - Huila, en el diagrama propuesto por Wang et al. (2012). Los circones de las muestras JGB-373 y GR-6643 grafican dentro del campo de los granitos Tipo I, la muestra GR6632 la mayoría de circones se localizan en el campo de granitos Tipo I pero un número importante pasan al campo de granitos Tipo S, con dispersión de los valores, mientras en la muestra GR-6631 los circones se localizan hacia el campo de los granitos Tipo S.

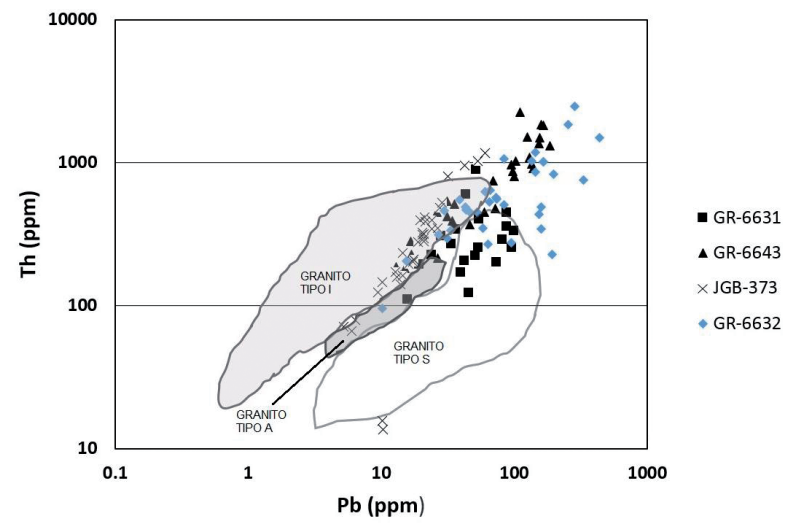

FIGURA 19. Diagrama de $\mathrm{Th} v s \mathrm{~Pb}$ para discriminación de tipo de granitoide modificado de Wang et al. (2012). Circones de muestras de edad Pérmica del occidente de La Plata y Pacarní - Huila.

\section{DISCUSIÓN}

La localización geotectónica del magmatismo de arco de edad Pérmica que aflora al occidente de Pacarní y La Plata-Huila, involucra un problema regional de límite de terrenos, entre el Terreno Tahamí y el Terreno Chibcha (Restrepo and Toussain, 1988; Restrepo et al., 2009), problema que se extiende hacia el norte a los demás cuerpos de edad Pérmica como es el caso del Neis de Nechí (Restrepo et al., 2010; Rodríguez et al., 2014). Las rocas de edad Pérmica del occidente de La Plata y Pacarní - Huila, se localiza dentro de un bloque limitado tectónicamente por la falla La Plata - Chusma al oriente y las fallas Avirama e Inza al occidente, afloran al interior y son intruidas por la Cuarzomonzodiorita de Páez (Zapata et al., 2015); parcialmente están cubiertas por depósitos volcánicos y volcanoclásticos recientes de la Formación Guacacallo. Este bloque está limitado al occidente por las Fallas Avirama e Inza que lo ponen en contacto con metamórfitas del Complejo Cajamarca (Terreno Tahamí) de probable edad Triásica. Al oriente, el bloque lo limita la Falla Chusma con metamórfitas de basamento Grainvilliano (Terreno Chibcha -Metamorfitas de Las Minas, Velandia et al., 2001). Un conjunto de datos permiten definir con mayor precisión el basamento del plutonismo Pérmico: 1- Las edades heredadas en circones de rocas de edad Pérmica, indican aporte de material de corteza más antigua (principalmente Grenvilliano) al plutonismo Pérmico; 2- Se localiza junto con rocas del arco Jurásico que se emplazó en el basamento Grenvilliano del Terreno Chibcha, sugiriendo que el magmatismo Pérmico se desarrolló en la margen occidental de este terreno.

Spikings et al. (2015) prefieren no considerar como un terreno el denominado Terreno Tahami conformado por basamento Triásico, más bien lo interpretan como una atenuación de la margen durante el Jurásico - Cretácico que permitió la yuxtaposición de un arco Cretácico temprano, basamento Paleozoico y Triásico, arco Jurásico tardío y arco Jurásico. Nosotros consideramos válido, pero con limitaciones espaciales al Terreno Tahami (Restrepo and Toussaint, 1988; Restrepo et al., 2009; Restrepo et al., 2011; Martens et al., 2014), el cual está constituido por un basamento metamórfico de edad Triásica, pero consideramos que entre los límites definidos para este terreno (Fallas Otú-Pericos al Este y Falla San Jerónimo al Oeste), hay bloques metamórficos y/o micro terrenos metamórficos del Paleozoico (Terreno Anacona -Restrepo et al., 2009; Martens et al., 2014), del Triásico (Terreno Tahami - Restrepo et al., 2009, Martens et al., 2014), del Jurásico (Blanco-Quintero et al., 2014) del límite Cretácico - Jurásico (Rodríguez y Correa-Martínez, 2015) y del Cretácico medio 
(Restrepo et al., 2012), siendo la historia geológica y el metamorfismo de la Cordillera Central de Colombia más compleja de lo previsto y constituida por bloques metamórficos o terrenos metamórficos de edades muy diversas en contactos fallados unos con otros, sin que el metamorfismo de bloques o terrenos más jóvenes afecte los otros bloques.

El problema del ambiente de formación de los granitos y migmatitas de edad Pérmica de La Plata y Pacarní, debe ser abordado desde los resultados obtenidos en el presente estudio. Las edades en todas las rocas (granitos y migmatitas) corresponden a la cristalización magmática, y no se obtuvieron edades del metamorfismo; adicionalmente, las imágenes de catodoluminiscencia muestran que los circones son euhedrales zonados, con relaciones $\mathrm{Th} / \mathrm{U}$ alrededor de 1 y con patrones de elementos de las REE con anomalías positiva de Ce y negativa de $\mathrm{Eu}$, típica de circones de origen ígneo. El protolito de las migmatitas es ígneo de acuerdo al diagrama de $\mathrm{Al}_{2} \mathrm{O}_{3}$ vs $\mathrm{MgO}$ de Marc et al. (1992); los diagramas de Harker muestran correlación lineal de los óxidos mayores versus $\mathrm{SiO}_{2}$, con las migmatíticas dentro del mismo tren de cristalización de los granitos, sugiriendo un origen común entre los diferentes tipos de rocas.

Los arañogramas de REE y elementos trazas obtenidos a partir de la química de roca total en granitos y migmatitas son comparables a los de rocas generadas en ambiente de arco de margen continental y afinidad calcoalcalina alta en K. Los REE se van empobreciendo progresivamente desde las Tierras Raras ligeras (LREE) hacia las tierras raras pesadas (HREE), con pendiente negativa, y patrón de elementos traza multielementales (Sun and McDonough, 1989), con anomalía negativa de los elementos inmóviles $\mathrm{Nb}$, Ti y P, característico de rocas formadas en ambiente de arcos magmáticos. Este resultado se corrobora con los diagramas de discriminación de ambiente tectónico.

Las rocas de edad Pérmica son afines a granitos Tipo I, aunque la química de elementos traza en circones no discrimina de manera inequívoca el tipo de granito al que corresponden, muestra tendencia cercana a los Tipo I y algunos a los $\mathrm{S}$, esto puede ser debido al avanzado grado de fraccionamiento de los granitos (monzogranitos y sienogranitos), que de acuerdo a Wang et al. (2012), existen dificultades para distinguir a partir de los elementos traza en circones entre los granitos tipos I y S altamente evolucionados.

Las edades U-Pb indican que el arco se desarrolló entre 280 Ma y $265 \mathrm{Ma}$ (Cisulariano - Guadalupiano), con la mayor cristalización alrededor de $270 \mathrm{Ma}$. Los circones presentan edades heredadas del Pérmico, Carbonífero, Devónico, Cámbrico, Neo-proterozoico, Meso-proterozoico y Paleo-proterozoico; herencias que sugieren aporte de los bloques de corteza continental que afloran al oriente de las rocas Pérmicas descritas en el presente estudio. Estas rocas junto con otros granitoides que afloran a lo largo de la margen oriental de la Cordillera Central de Colombia, la Serranía de San Lucas (Gneis de Nechí y otros granitoides menores) y la Sierra Nevada de Santa Marta (granitoides miloníticos), (Restrepo et al., 2010; Leal-Mejía, 2011; Rodríguez et al., 2014; Cardona et al., 2010), representan bloques del arco Pérmico localizado a lo largo del límite entre el basamento Grenvilliano al oriente de los Andes y el basamento metamórfico Triásico al occidente. Las rocas analizadas en este estudio (granitos Pérmicos), se formaron en una margen relacionada a ambiente de subducción, y corresponden a granitoides subalcalinos metaluminosos y peraluminosos, de la serie calcoalcalina alta en $\mathrm{K}$, constituidos por cuarzodioritas, tonalitas, granodioritas, monzogranitos y sienogranitos. Las rocas Pérmicas que afloran al occidente de La Plata aparecen junto a rocas con estructuras migmatíticas (granofels), sin que exista diferencias en las edades de cristalización entre las rocas graníticas y migmatíticas, sugiriendo que todas cristalizaron a partir del mismo arco.

Pocos datos han sido obtenidos del metamorfismo que afecto los protolitos ígneos del arco Pérmico a lo largo de los Andes en Colombia: los únicos datos publicados corresponden al trabajo de Restrepo et al. (2010), en el Gneis de Nechí, donde algunos bordes de circones con crecimiento metamórfico arrojaron edad Triásica de $236,4 \pm 6,6 \mathrm{Ma}$, interpretada como metamorfismo posterior Triásico que afecto las rocas intrusivas y correlacionado con el metamorfismo del Terreno Tahamí. En el presente estudio no se obtuvieron edades de metamorfismo, por tal razón no podemos determinar cuando fueron afectadas las rocas del denominado Ortogranito de La Plata por un evento posterior de metamorfismo, pero creemos poco probable que el metamorfismo que afecto el Terreno Tahami en el Triásico haya afectado el arco Pérmico que se encuentra asociado al Terreno Chibcha, más cuando existen en el basamento metamórfico de la Cordillera Central bloques metamórficos Paleozoicos (Terreno Anacona -Restrepo et al., 2009; Martens et al., 2014), Triásico (Terreno Tahami - Restrepo et al., 2009, Martens et al., 2014), Jurásicos (Blanco-Quintero et al., 2014) del límite Cretácico - Jurásico (Rodríguez y CorreaMartínez, 2015) y del Cretácico medio (Restrepo et al., 2012) donde no se ha detectado polimetamorfísmo sobre impuestos de estos eventos. 
Sobre las rocas metamórficas del Ortogranito de La Plata descritas por Rodríguez (1995a) y que sirvieron de base al trabajo de Velandia et al. (2001), no se han hecho nuevos trabajos de reconocimiento y descripción de esta unidad posteriores a estos trabajos, por tal razón las descripciones que indican la transición litológica gradual entre rocas migmatíticas que ocurren en los bordes y los granitos al interior del cuerpo y el origen anatéctico para los granitos, no se aborda y más bien se analiza la cristalización contemporánea de todas las rocas. El presente estudio con base en datos geocronológicos muestran edades similares de cristalización entre las rocas migmatíticas del Ortogranito de La Plata y rocas graníticas que afloran al sur de esta unidad y cerca de Río Chiquito-Huila, las cuales en los mapas geológicos de Rodríguez et al. (1998) y Marquínez et al. (2002, 2003) fueron cartografiados como parte de los plutones jurásicos (Batolito de Ibagué). Los nuevos datos de geoquímica y geocronología sugieren un origen ígneo común para migmatitas y granitos dentro de un ambiente de arco. El problema del metamorfismo que afecta parte de las rocas Pérmicas no es posible resolverlo con los datos de geocronología obtenidos, puesto que no se tienen edades de metamorfismo y las edades que se presentan son de cristalización magmática, además, los datos de química de roca sugieren un ambiente geotectónico y un desarrollo común dentro de un arco.

El nombre de Ortogranito de La Plata propuesto por Velandia et al. (2001), consideramos que no es adecuado para una unidad de origen ígneo plutónico que localmente muestra afectación metamórfica con desarrollo de migmatitas. La unidad está constituida preferentemente por rocas con textura y composición típica de granitos ígneos, en este sentido proponemos el nombre de Granito de La Plata para agrupar las rocas Pérmicas que aflora al occidente de La Plata constituidas por granitos y migmatitas y las rocas Pérmicas que aflora al occidente de Pacarní - Huila.

Sobre algunos modelos propuestos para las rocas Permo Triásicas en el norte de los Andes, como el de Cochrane et al. (2014) que proponen que el magmatismo de 270 a 240 Ma se debió a una zona de subducción hacia el este durante la formación de Pangea y la anatexia fue consecuencia de una colisión; el de Weber et al. (2007) y Cardona et al. (2010) que sugieren que los granitos del Pérmico tardío al Triásico temprano se habrían formado por engrosamiento cortical durante la formación de Pangea. En base al presente estudio creemos que es importante indicar que pudieron existir diferentes eventos de plutonismo durante el Permo-Triásico, con diferente localización geográfica: los granitos Pérmicos de arco con edades alrededor de $270 \mathrm{Ma}$ se localizan en el borde occidental del basamento Precámbrico y los granitoides tipo $\mathrm{S}$ del límite Permo-Triásicos se localizan en el basamento metamórfico de la Cordillera Central con un origen completamente diferente.

\section{CONCLUSIONES}

Los resultados de este trabajo permiten extender el área de afloramiento de las rocas Pérmicas más al norte y sur de los afloramientos anteriores definidos por Rodríguez (1995a), Rodríguez et al. (1998), Velandia et al. (2001), Leal-Mejía (2011) y Marquínez et al. (2002, 2003). La unidad aflora en las Hojas Geológicas 344, 366, 388 y 389 (FIGURA 1), que anteriormente habían sido asignadas como parte del Batolito de Ibagué de edad jurásica (Velandia et al., 2001). Esta nueva delimitación de las rocas Pérmicas de La Plata fue posible a partir de los resultados de las edades $\mathrm{U}-\mathrm{Pb}$ en circones obtenidas en este trabajo y análisis de litogeoquímica.

El ambiente geotectónico de formación de granitos y migmatitas es de arco, desarrollado en la margen occidental del Terreno Chibcha o si se prefiere en el borde occidental del basamento Grenvilliano. Se formó entre 280 Ma y 265 Ma (Cisulariano - Guadalupiano), con la mayoría de edades promedias de cristalización cercana a los $270 \mathrm{Ma}$. El arco Pérmico se extiende a otros bloques de la Cordillera Central, la Serranía de San Lucas y la Sierra Nevada de Santa Marta en una posición geotectónica igual: la margen occidental del Terreno Chibcha.

No se tienen datos para concluir sobre la edad del metamorfismo que afecta algunas rocas Pérmicas al occidente de La Plata, puesto que los resultados geocronológicos no arrojaron edades de metamorfismo, por tal razón no se sabe la edad y origen de este metamorfismo y no sabemos si se puede correlacionar con el descrito en el Gneis de Nechí más al norte de los Andes.

\section{AGRADECIMIENTOS}

Los autores expresan su agradecimiento al Servicio Geológico Colombiano por el apoyo en el desarrollo del proyecto "Magmatismo Jurásico en el Valle Superior del Magdalena", especialmente por llevar a cabo el convenio con el laboratorio de estudios isotópicos (LEI) en el Centro de Geociencias de la Universidad Nacional Autónoma de México (UNAM). Especial agradecimiento a todos los revisores, entre ellos a Cristian Vallejo por sus observaciones y correcciones que ayudaron a mejorar este artículo. 


\section{REFERENCIAS}

Álvarez, A.J. 1979. Geología de la Cordillera Central y el Occidente Colombiano y petroquímica de los intrusivos granitoides mezo-cenozoicos. Tesis de doctorado, Universidad de Chile, Santiago de Chile. 359p.

Álvarez, J., y Linares, E. 1983. Edad K-Ar del plutón granitoide de La Plata. Departamento del Huila (Colombia). Geología Norandina, 7: 3-38, Bogotá.

Arango, M.I., Rodríguez, G., Bermúdez, J., y Zapata, G. 2015. Cuarzomonzonita de Anchique. Catálogo de unidades litoestratigráficas de Colombia, Servicio Geológico Colombiano. 26p.

Arvizu, H.E., Iriondo, A., Izaguirre, A., Chávez-Cabello, G., Kamenov, G.D., Solís-Pichardo, G., Foster, D.A., y Lozano-Santa Cruz, R. 2009. Rocas graníticas pérmicas en la Sierra Pinta, NW de Sonora, México: Magmatismo de subducción asociado al inicio del margen continental activo del SW de Norteamérica. Revista Mexicana de Ciencias Geológicas, 26(3): 709-728.

Belousova, E.A., Griffin, W.L., and O'Reilly, S.Y. 2006. Zircon crystal morphology, trace element signatures and $\mathrm{Hf}$ isotope composition as a tool for petrogenetic modelling: examples from eastern Australian granitoids. Journal of Petrology, 47(2): 329-353.

Bermúdez, J.G., Arango, M.I., Rodríguez, G., y Zapata, G. 2015. Cuarzomonzodiorita de San Cayetano. Catálogo de unidades litoestratigráficas de Colombia. Servicio Geológico Colombiano. 26p.

Blanco-Quintero, I.F., García-Casco, A., Toro, L.M., Moreno, M., Ruiz, E. C., Vinasco, C.J., Cardona, A., Lázaro, C., and Morata, D. 2014. Late Jurassic terrane collision in the northwestern margin of Gondwana (Cajamarca Complex, eastern flank of the Central Cordillera, Colombia). International Geology Review, 56(15): 1852-1872.

Botero, G. 1963. Contribución al conocimiento de la geología de la Zona Central de Antioquia. Anales de la Facultad de Minas, 57: 1-101.

Cardona, A., Valencia, V., Garzón, A., Montes, C., Ojeda, G., Ruiz, J., and Weber, M. 2010. Permian to Triassic I to S-type magmatic switch in the northeast Sierra Nevada de Santa Marta and adjacent regions, Colombian Caribbean: Tectonic setting and implications within Pangea paleogeography. Journal of South American Earth Sciences, (29): 772-783.
Cediel, F., Mojica, J., y Macía, C. 1980. Definición estratigráfica del Triásico en Colombia, Suramérica. Formaciones Luisa, Payandé y Saldaña. Newsletter on Stratigraphy, 9(2): 73-104.

Cediel, F., Mojica, J., y Macía, C. 1981. Las Formaciones Luisa, Payandé y Saldaña. Sus columnas estratigráficas características. Geología Norandina, 3: 12-19.

Cochrane, R., Spikings, R., Gerdes, A., Ulianov, A., Mora, A., Villagómez, D., Putlitz, B., and Chiaradia, M. 2014. Permo-Triassic anatexis, continental rifting and the disassembly of western Pangaea. Lithos, 190-191: $383-402$.

Debon, F., and Le Fort, P. 1983. A chemicalmineralogical classification of common plutonic rocks and associations. Transactions of the Royal Society of Edinburgh: Earth Sciences, 73(3): 135-149.

Ferreira, P., Núñez, A., y Rodríguez, M. 2002. Levantamiento Geológico de la plancha 323 Neiva. Escala 1:100.000. Memoria Explicativa. Servicio Geológico Colombiano.

Fuquen, J., y Núñez, A. 1989. Memoria explicativa del mapa geológico generalizado del Departamento del Huila. Geología, recursos minerales y amenazas geológicas. INGEOMINAS, 41p. Bogotá.

González, H. 1980. Geología de las planchas 167 (Sonsón) y 187 (Salamina) del Mapa Geológico de Colombia. Boletín Geológico, INGEOMINAS, 23(1): 1-174.

Grosse, E. 1935. Acerca de la geología del sur de Colombia. Informe $2^{\circ}$ rendido al Ministerio de Industrias sobre un viaje al Huila y alto Caquetá. CEGOC, (3): 31137, Bogotá.

Hall, R., Alvarez, J., y Rico, H. 1972. Geología de la parte de los departamentos de Antioquia y Caldas (Subzona II-A). Boletín Geológico, INGEOMINAS, 20(1): 1-85. Bogotá.

Harris, N.W., Pearce, J.A., and Tindle, A. 1986. Geochemical characteristics of collision zone magmatism. In: Coward, M.P., and Ries, A.C. (eds.). Collision tectonics, Geology, Society, Special Publication, (19): 67-81.

Heinrich, E.W.M. 1970. Identificación microscópica de minerales. McGraw Hill, New York, 256p. 
Hoskin, P.W.O., and Schaltegger, U. 2003. The composition of zircon and igneous and metamorphic petrogenesis. Reviews in Mineralogy and Geochemistry, 53: 27-62.

Hubach, E., y Alvarado, B. 1932. Estudios geológicos en la ruta Popayán - Bogotá, Servicio Geológico Nacional. Informe 213, 132p, Bogotá.

Feininger, T., Barrero, D., y Castro, N. 1972. Geología de parte de los departamentos de Antioquia y Caldas (Subzona II-B). Boletín Geológico, INGEOMINAS, 20(2): 1-176. Bogotá.

Kroonenberg, S., León, L., Pastana, J., and Pessoa, M. 1981. Ignimbritas pliopleistocénicas en el suroeste del Huila, Colombia y su influencia en el desarrollo morfológico. Revista CIAF, 6(1-3): 293-314.

Kroonenberg, S. 1982. A Grenvillian granulite belt in the Colombian Andes and Relations to the Guiana Shield. Geologie en Mijnbouw, 61(4): 325-333.

Leal-Mejía, H. 2011. Phanerozoic gold metallogeny in the Colombian Andes: A tectonomagmatic approach. PhD Thesis. Universitat de Barcelona, 989p.

Litherland, M., Aspden, J.A., and Jemielita, R.A. 1994. The metamorphic belts of Ecuador. British Geological Survey, Vol. 11. Nottingham, p. 147.

Ludwig, K.R. 2008. Manual for Isoplot 3.7: Berkeley Geochronology Center, Special Publication No, 4, 77 p.

Ludwig, K.R. 2012. User's Manual for Isoplot 3.75-4.15. A Geochronological Toolkit Microsoft Excel. Berkeley Geochronology Center, Special Publication N 5 , 75p.

Marc, D., Leeman, W., and Mertzman, S.A. 1992. Granites and rhyolites from the northwestern USA: temporal variation in magmatic processes and relations to tectonic setting. Transactions of the Royal Society of Edinburgh: Earth Sciences, 83: 71-81.

Marquínez, G., Morales, C. J., y Caicedo, J. C. 2002. Memoria explicativa plancha 344 - Tesalia. INGEOMINAS, 140p.

Marquínez, G., Rodríguez, Y., y Fuquen, J.A. 2003. Memoria explicativa Plancha 365 Coconuco, Escala 1: 100.000. INGEOMINAS, 116p. Bogotá.

McDonough, W.F., and Sun, S.S. 1995. Composition of the Earth. Chemical Geology, 120(3-4): 223-253.
Martens, U., Restrepo, J.J, Ordoñez, O., and Correa, A. 2014. The Tahamí and Anacona terranes of the Colombian Andes: Missing links between the South American and Mexican Gondwana margins. The Journal of Geology, 122(5): 507-530.

Middlemost, E.A.K. 1984. Naming materials in the magma/igneous rock system. Earth- Sciences Reviews, 37(3-4): 215-224.

Mojica, J., Villarroel, C., y Macía, C. 1988. Nuevos afloramientos fosilíferos del Ordovícico Medio (Fm. El Hígado) al oeste de Tarqui, Valle Superior del Magdalena (Huila, Colombia). Geología Colombiana, 16: 95-97.

Paton, C., Woodhead, J.D., Hellstrom, J.C., Hergt, J.M., Greig, A., and Maas, R. 2010. Improved laser ablation $\mathrm{U}-\mathrm{Pb}$ zircon geochronology through robust downhole fractionation correction. Geochemistry Geophysics Geosystems, 11: 1-36.

Pearce, J.A., Harris, N.B., and Tindle, A.G. 1984. Trace element discrimination diagrams for the tectonic interpretation of granitic rocks. Journal of Petrology, 25(4): 956-983.

Pearce, J.A. 1996. A user's guide to basalt discrimination diagrams. Association géologuique du Canada, short course notes Volume 12: 79-113.

Pearce, J.A. 2008. Geochemical fingerprinting of oceanic basalts with applications to ophiolite classification and the search for Archean oceanic crust. Lithos, 100(1-4): $14-48$

Pearce, J.A. 2014. Geochemical fingerprinting of the Earth's oldest rocks. Geology, 42(2): 175-176.

Peccerillo, A., and Taylor, S.R. 1976. Geochemistry of eocene calc-alkaline volcanic rocks from the Kastamonu area, Northern Turkey. Contributions to Mineralogy and Petrology, 58(1): 63-81.

Petrus, J.A, and Kamber, B.S. 2012. VizualAge: A novel approach to laser ablation ICP-MS U-Pb geochronology data reduction. Geostandards and Geoanalytical Research, 36(3): 247-270.

Priem, H.N.A., Kroonenberg, S.B., Boelrijk, N.A., and Hebeda, E.H. 1989. Rb-Sr and K-Ar evidence for the presence of a $1.6 \mathrm{Ga}$ basement underlying the $1.2 \mathrm{Ga}$ Garzón-Santa Marta granulite belt in the Colombian Andes. Precambrian Research, 42(3-4): 315-324. 
Restrepo, J.J., and Toussaint, J.F. 1988. Terranes and continental accretion in the Colombian Andes. Episodes, 11(3):189-193.

Restrepo, J.J., Ordóñez-Carmona, O., Martens, U., y Correa, A.M. 2009. Terrenos, complejos y provincias en la Cordillera Central Colombiana. Ingeniería, Investigación y Desarrollo, 9(2): 49-56.

Restrepo, J.J., Ordoñez-Carmona, O., and Armstrog, R. 2010. Triassic metamorphism in the northern part of the Central Cordillera of Colombia. VII SSAGI South American Symposium on Isotope Geology, Brasilia, 405-408p.

Restrepo, J.J., Ordóñez-Carmona, O., Armstrong, R., and Pimentel, M.M. 2011. Triassic metamorphism in the northern part of the Tahamí Terrane of the central cordillera of Colombia. Journal of South American Earth Sciences, 32(4) :497-507.

Restrepo, J.J., Ibañez-Mejía, M., and García-Casco, A. 2012. U-Pb zircon ages of the Medellin Amphibolites (Central Cordillera of Colombia) reveal mid-Cretaceous tectonic juxtaposition of Triassic and mid-Cretaceous metamorphic complexes. VIII Simposio Sudamericano de Geología Isotópica, Medellín, Colombia: 201-202p.

Rodríguez, G. 1995a. Petrografía del Macizo de La Plata, Departamento del Huila. Revista Ingeominas, (5): 5-16.

Rodríguez, G. 1995b. Petrografía y microestructuras del Grupo Garzón y el Granito de Anatexis de El Recreo, Macizo de Garzón Cordillera Oriental-Colombia. Revista Ingeominas, 5: 17- 36.

Rodríguez, G., Ferreira, P., Velandia, F., y Núñez, A. 1998. Geología de la plancha 366 Garzón, INGEOMINAS, Bogotá.

Rodriguez, G., González, H., Zapata, G., y Cossio, U. 2005. Geología de la plancha 147 Medellín Oriental. INGEOMINAS, 320p. Bogotá.

Rodríguez, G., Arango, M.I., Zapata, G., y Bermúdez, J.G. 2014. Petrografía y geoquímica del Neis de Nechí. Boletín de Geología, 36(1): 71-84.

Rodríguez, G., Arango, M.I., Bermúdez, J.G., y Zapata, G. 2015. Cuarzomonzonita de Los Naranjos. Catálogo de unidades litoestratigráficas de Colombia, Servicio Geológico Colombiano, 28p.
Rodríguez, G., y Correa-Martínez, A.M. 2015. Edades $\mathrm{U}-\mathrm{Pb}$ en circón de varias unidades metamórficas al este y noreste de la ciudad de Medellín, Cordillera Central de Colombia. XV Congreso Colombiano de Geología, Bucaramanga, Colombia, pp. 287- 289.

Rodríguez, G., Arango, M.I., Zapata, G., y Bermúdez, J.G. 2016. Formación Saldaña. Catálogo de unidades litoestratigráficas de Colombia. Servicio Geológico Colombiano, 61p.

Rubatto, D. 2002 Zircon trace element geochemistry: partitioning with garnet and the link between $\mathrm{U}-\mathrm{Pb}$ ages and metamorphism. Chemical Geology, 184(1-2): 123138.

Schoene, B. 2014. U-Th-Pb Geochronology. Princeton University, 341-368 p.

Shand, S.J. 1943. Eruptive rocks, their genesis, composition, classification, and their relation to oredeposits, with a chapter on meteorites. John Wiley and Sons. New York.

Spikings, R., Cochrane, R., Villagomez, D., Van der Lelij, R., Vallejo, C., Winkler, W., and Beate, B. 2015. The geological history of northwestern South America: from Pangaea to the early collision of the Caribbean Large Igneous Province (290-75 Ma). Gondwana Research, 27(1): 95-139.

Spry, A. 1969. Metamorphic textures. Pergamon press, Oxford, 350p.

Stacey, J.S., and Kramers, J.D. 1975. Approximation of terrestrial lead isotope evolution by a 2-stage model. Earth and Planetary Science Letters, 26(2): 207-221.

Stibane, F., y Forero, A. 1969. Los afloramientos del Paleozoico en La Jagua (Huila) y río Nevado (Santander del Sur). Geología Colmbiana, 6: 31-66.

Streckeisen, A.L. 1976. Classification of the common igneous rocks by means of their chemical composition: a provisional attempt. Neues Jahrbuch fuer Mineralogie, Monatshefte, H, 1: 1-15.

Solari, L., Gómez-Tuena, A., Bernal, J., Pérez-Arvizu, O., and Tanner, M. 2010. U-Pb zircon geochronology with an integrated LA-ICP-MS microanalytical workstation: Achievements in precision and accuracy. Geostandards and Geoanalytical Research, 34(1): 5-18. 
Sun, S.S., and McDonough, W.F. 1989. Chemical and isotopic systematics of oceanic basalts: implications for mantle composition and processes. In: Saunders, A.D., and Norry, M.J. (Eds.). Magmatism in the ocean basins, Geological Society, London, Special Publications, 42: 313-345.

Toussaint, J.F., González, H., Restrepo, J.J., y Linares, E. 1978. Edad K-Ar de tres rocas metamórficas del flanco noroccidental de la Cordillera Central. Boletín de Ciencias de la Tierra, 14: 1-7.

Velandia, F., Ferreira, P., Rodríguez, G., y Núñez, A, 1996. Memoria explicativa levantamiento geológico de la Plancha 366 Garzón. INGEOMINAS, Informe 1321, 122p. Bogotá.

Velandia, F., Morales, C., Caicedo, J., y Núñez, A. 1999. Geología de la Plancha 345 Campoalegre. Escala 1: 100.000. INGEOMINAS. Bogotá.

Velandia, F., Ferreira, P., Rodríguez, G., y Núñez, A. 2001. Levantamiento geológico de la plancha 366 Garzón, Memoria explicativa. INGEOMINAS, Bogotá.

Villarroel, C., y Mojica, J. 1988. El Paleozoico superior (Carbonífero - Pérmico) sedimentario de Colombia: Afloramientos conocidos y características generales. Geología Colombiana, 16: 81-87.

Villaseca, C., Barbero, L., and Herreros, V. 1998. A reexamination of the typology of peraluminous granite types in intracontinental orogenic belts. Transactions of the Royal Society of Edinburgh: Earth Sciences, 89(2): 113-119.

Vinasco, C., Cordani, U.G., González, H., Weber, M., and Pelaez, C. 2006. Geochronological, isotopic, and geochemical data from Permo-Triassic granitic gneises and granitoids of the Colombian Central Andes. Journal of South American Earth Sciences, 21(4): 355-371.

Wang, Q., Zhu, D.C., Zhao, Z.D., Guan, Q., Zhang, X.Q., Sui, Q.L., Hu, Z.C., and Mo, X.X. 2012. Magmatic zircons from I-, S- and A-type granitoids in Tibet: Trace element characteristics and their application to detrital zircon provenance study. Journal of Asian Earth Sciences, 53: 59-66.

Weber, B., Iriondo, A., Premo, W.R., Hecht, L., and Schaaf, P. 2007. New insights into the history and origin of the southern Maya block, SE Mexico: U-Pb-SHRIMP zircon geochronology from metamorphic rocks of the
Chiapas massif. International Journal of Earth Sciences, 96(2): 253-269.

Weber, M., Cardona, A., Valencia, V., García-Casco, A., Tobón, M., and Zapata, S. 2010. U/Pb detrital zircon provenance from late cretaceous metamorphic units of the Guajira Peninsula, Colombia: Tectonic implications on the collision between the Caribbean arc and the South American margin. Journal of South American Earth Sciences, 29(4): 808-816.

Wilson, B.M. 1989. Igneous petrogenesis. A global tectonic approach. Unwin Hyman, London, 480p.

Winter, J.D. 2001. An introduction to igneous and metamorphic petrology. Prentice Hall, New Jersey, $647 \mathrm{p}$.

Zapata, G., Rodríguez, G., Arango, M.I., y Bermúdez, J.G. 2015. Cuarzomonzodiorita de Páez. Catálogo de unidades litoestratigráficas de Colombia, Servicio Geológico Colombiano, 51p.

Trabajo recibido: abril 01 de 2016

Trabajo aceptado: noviembre 08 de 2016

Manuscrito publicado en internet: diciembre 05 de 2016 